\title{
Article \\ Photocatalytic Perfomance of ZnO-Graphene Oxide Composites towards the Degradation of Vanillic Acid under Solar Radiation and Visible-LED
}

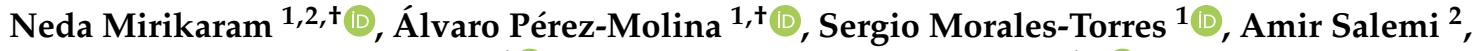 \\ Francisco J. Maldonado-Hódar ${ }^{1}$ (D) and Luisa M. Pastrana-Martínez ${ }^{1, *(D)}$ \\ 1 Department of Inorganic Chemistry, Faculty of Sciences, University of Granada, Avda. Fuente Nueva s/n, \\ ES-18071 Granada, Spain; mirikaram@gmail.com (N.M.); alpemo@ugr.es (Á.P.-M.); semoto@ugr.es (S.M.-T.); \\ fjmaldon@ugr.es (F.J.M.-H.) \\ 2 Environmental Sciences Research Institute, Shahid Beheshti University, Tehran 19839-63113, Iran; \\ a_salemi@sbu.ac.ir \\ * Correspondence: lpastrana@ugr.es; Tel.: +34-(958)-248-489 \\ + The authors contributed equally to this study.
}

Citation: Mirikaram, N.;

Pérez-Molina, Á.; Morales-Torres, S.; Salemi, A.; Maldonado-Hódar, F.J.;

Pastrana-Martínez, L.M.

Photocatalytic Perfomance of

ZnO-Graphene Oxide Composites towards the Degradation of Vanillic Acid under Solar Radiation and Visible-LED. Nanomaterials 2021, 11, 1576. https://doi.org/10.3390/ nano11061576

Academic Editor: Vincenzo Vaiano

Received: 27 April 2021

Accepted: 11 June 2021

Published: 15 June 2021

Publisher's Note: MDPI stays neutral with regard to jurisdictional claims in published maps and institutional affiliations.

Copyright: (C) 2021 by the authors. Licensee MDPI, Basel, Switzerland. This article is an open access article distributed under the terms and conditions of the Creative Commons Attribution (CC BY) license (https:// creativecommons.org/licenses/by/ $4.0 /)$.
Abstract: Graphene oxide (GO) is used to enhance the photocatalytic activity of $\mathrm{ZnO}$ nanoparticles for the degradation of vanillic acid (VA) under simulated solar light and visible-LED $(\lambda>430 \mathrm{~nm})$. ZnO-GO composites are prepared by a mixing and sonication process with different $\mathrm{GO}$ loadings (i.e., from 1.8 to $6.5 \mathrm{wt} . \%$ ). The materials are extensively characterized by thermogravimetric analysis (TGA), physisorption of $\mathrm{N}_{2}$, X-ray diffraction (XRD), infrared spectroscopy (FTIR), scanning electron microscopy (SEM), point of zero charge ( $\mathrm{pH}_{\mathrm{PZC}}$ ), and UV-Vis diffuse reflectance spectroscopy (DRUV). The presence of GO increases the photocatalytic activity of all the prepared composites in comparison with the pristine $\mathrm{ZnO}$. The highest photocatalytic activity is found for the composite containing 5.5 wt. $\%$ of GO (i.e., ZnO-GO5.5), reaching a VA degradation of $99 \%$ and $35 \%$ under solar light and visible-LED, respectively. Higher TOC removal/VA degradation ratios are obtained from the experiments carried out under visible-LED, indicating a more effective process for the mineralization of VA than those observed under simulated solar light. The influence of hole, radical, and non-radical scavengers is studied in order to assess the occurrence of the reactive oxygen species (ROS) involved in the photocatalytic mechanism. The study of the photo-stability during three reuse experiments indicates that the presence of GO in the composites reduces the photocorrosion in comparison with pristine $\mathrm{ZnO}$.

Keywords: graphene oxide; $\mathrm{ZnO}$; vanillic acid; water treatment; scavengers

\section{Introduction}

Over the past 40 years, advanced oxidation processes (AOPs) have been successfully applied to manage the problematic issues associated to water, air, and soil pollution [1] These processes are mainly based on the generation of hydroxyl radicals $\left(\mathrm{HO}^{\bullet}\right)$ which can generate a sequence of reactions capable of degrading contaminants into $\mathrm{CO}_{2}$ and $\mathrm{H}_{2} \mathrm{O}$, or converting them into less toxic organic compounds. These processes include heterogeneous photocatalysis, which is based on the effective utilization of ultraviolet (UV) or solar irradiation as a technology for environmental applications [2]. On the other hand, many structural materials including polymers, metals, ceramics, glasses, and composite materials have been synthetized for different industrial applications [3-8].

Normally, metal oxides such as titanium dioxide $\left(\mathrm{TiO}_{2}\right)$, zinc oxide $(\mathrm{ZnO})$, zirconia $\left(\mathrm{ZrO}_{2}\right)$, tungsten trioxide $\left(\mathrm{WO}_{3}\right)$, and vanadium oxide $\left(\mathrm{V}_{2} \mathrm{O}_{5}\right)$, have been used as semiconductor photocatalysts for water and air decontamination, as well as for energy applications [9-12]. $\mathrm{ZnO}$ is an n-type semiconductor with a band gap ca. $3.22 \mathrm{eV}$ and a large excitation binding energy of ca. $60 \mathrm{meV}$. It can be considered as a suitable successor of 
the benchmark $\mathrm{TiO}_{2}$ semiconductor due to its similar properties such as strong oxidation ability, good photocatalytic properties, chemical stability, biocompatibility, non-toxicity, high photosensitivity, and electronic and piezoelectric properties, among others [13-15]. This semiconductor usually exists in one-dimensional (1D), two-dimensional (2D) and three-dimensional (3D) associations [16], and has been used in a wide range of applications, such as sensors [17], photocatalysis [14,18-21], transistors, solar cells [22,23], etc. It is well known that the use of $\mathrm{ZnO}$ in photocatalysis displays some drawbacks such as: (i) the limitation of its use in the visible range due to its wide band gap [24]; (ii) particle aggregation during photocatalytic reactions which significantly restrict the photocatalytic activity of $\mathrm{ZnO}$ at a large scale [25]; and (iii) the rapid recombination of the photogenerated electron-hole pairs [26,27].

Many strategies have been carried out to improve the photocatalytic performance of $\mathrm{ZnO}$, e.g., the design of suitable sizes and morphologies [28,29], noble metal loading [14,30,31], heteroatom doping [32-34], or by forming semiconductor composites [35], among others. In particular, the design and development of hybrids based on the coupling of carbon materials and $\mathrm{ZnO}$ is an effective option for enhancing its photocatalytic response under UV/Vis irradiation [18,36-38], by inhibiting the electron-hole recombination as well as extending the light absorption into visible range [39].

Amongst the vast number of carbon nanomaterials, graphene and its derivatives have been shown to significantly enlarge the photocatalytic degradation activity of $\mathrm{ZnO}$ in the field of photocatalytic wastewater treatment [37,40-43]. Of particular interest is the use of one of the most well-known derivatives of graphene, i.e., graphene oxide (GO), for the synthesis of $\mathrm{ZnO}-\mathrm{GO}$ hybrid materials, as the presence of oxygen-containing surface groups in GO offers an excellent dispersibility in polar solvents for the synthesis of the composites. Furthermore, GO can improve the photocatalytic efficiency in the composites by: (i) acting as an electron-acceptor, hindering the electron-hole recombination; (ii) increasing the adsorption of organic pollutants through $\pi-\pi$ interactions between the $s p^{2}$ region of graphene and the aromatic pollutant; and (iii) creating oxygen vacancies in the lattice of $\mathrm{ZnO}$, extending its response under the visible light region [35,37,42,44,45]. Various methods have been reported for the synthesis of $\mathrm{ZnO}-\mathrm{GO}$ composites, such as hydrothermal process [46,47], chemical vapor deposition (CVD) [35,48,49], physical vapor deposition (PVD) [50,51], pulsed laser deposition (PLD) [52], spray pyrolysis [53,54], solvothermal [19], and microwave synthesis [55], among others.

In this paper, we report a low-cost and scaling up method for the synthesis of $\mathrm{ZnO}-\mathrm{GO}$ composites. Nanostructured $\mathrm{ZnO}$ particles were formed using zinc acetate as precursor, then the composites were synthetized by a simple mixing and sonication method. The photocatalytic performance of the prepared materials was tested in the degradation of a phenolic compound, namely vanillic acid (VA), under both simulated solar irradiation and visible-LED $(\lambda>430 \mathrm{~nm})$. VA is a model compound typically present in the phenolic fractions of olive mill wastewater (OMW). The presence of this phenolic compound constitutes an important environmental problem, especially in Mediterranean countries and, in particular, areas of southern Spain, where a great number of plants are involved in the production and refining of olive oil [56].

\section{Materials and Methods}

\subsection{Synthesis of $\mathrm{GO}, \mathrm{ZnO}$ and $\mathrm{ZnO}-\mathrm{GO}$ Composites}

Graphite oxide was prepared using a modified Hummers' method [57,58]. Specifically, $5 \mathrm{~g}$ of graphite (powder $<20 \mu \mathrm{m}$, Sigma-Aldrich, St. Louis, MO, USA) and $5 \mathrm{~g}$ of sodium nitrate, $\mathrm{NaNO}_{3}(99.0 \%$, Acros Organics, Geel, Belgium) were put into $240 \mathrm{~mL}$ of concentrated sulfuric acid, $\mathrm{H}_{2} \mathrm{SO}_{4}$ (96-99\%, supplied by PanReac AppliChem, Darmstadt, Germany). The mixture was kept stirring for $30 \mathrm{~min}$ in an ice bath to prevent the temperature exceeding $10{ }^{\circ} \mathrm{C}$. Thereafter, $30 \mathrm{~g}$ of potassium permanganate, $\mathrm{KMnO}_{4}(99.0 \%$, PanReac AppliChem, Darmstadt, Germany) was added gradually with stirring (30 min). The ice bath was then removed, and the mixture was warmed at $35^{\circ} \mathrm{C}$ and stirred for $24 \mathrm{~h}$. 
The reaction was terminated by slowly adding $800 \mathrm{~mL}$ of distilled water and $30 \mathrm{~mL}$ of $30 \%$ hydrogen peroxide, $\mathrm{H}_{2} \mathrm{O}_{2}(30 \% w / w$, PanReac AppliChem, Darmstadt, Germany) solution. Finally, the resulting dispersion was filtered and washed repeatedly with distilled water until its $\mathrm{pH}$ became neutral. The acquired solid (i.e., graphite oxide) was dried in an oven at $60{ }^{\circ} \mathrm{C}$. Graphene oxide (GO) was prepared by sonication in an aqueous solution using an ultrasound bath (ultrasonic processor UP400S, $24 \mathrm{kHz}$, Hielscher, Germany). The undissolved solid was removed by centrifugation for $30 \mathrm{~min}$ at $3000 \mathrm{rpm}$ to obtain the GO suspension $\left(1 \mathrm{~g} \mathrm{~L}^{-1}\right)$.

$\mathrm{ZnO}$ nanoparticles were prepared by calcination of zinc acetate dihydrate, $\mathrm{Zn}(\mathrm{Ac})_{2}$ $2 \mathrm{H}_{2} \mathrm{O}\left(\geq 99.0 \%\right.$, Alfa Aesar, Haverhill, MA, USA) in a furnace with air flow at $5{ }^{\circ} \mathrm{C} \mathrm{min}{ }^{-1}$ until $600{ }^{\circ} \mathrm{C}$, with a soak time of $3 \mathrm{~h}$ [59]. ZnO-GO composites were synthesized by a sonication method $[38,60]$. Briefly, the required amount of $\mathrm{ZnO}$ was added to different amounts of an aqueous GO dispersion $\left(1 \mathrm{~g} \mathrm{~L}^{-1}\right)$ and ethanol $(96 \% \mathrm{v} / \mathrm{v})$ mixture in a proportion of 1:2, respectively. The resulting dispersion was kept under vigorous agitation for $30 \mathrm{~min}$, then sonicated for $2 \mathrm{~h}$ in an ultrasound bath (ultrasonic processor UP400S, $24 \mathrm{kHz}$, Hielscher, Germany). The obtained composites were filtered, washed with ultrapure water, and dried at $120^{\circ} \mathrm{C}$ in a vacuum oven for $8 \mathrm{~h}$. The GO loading was fitted at ca. 2, 3, 5, and 7 wt. $\%$.

\subsection{Characterization Techniques}

Infrared spectra (ATR-IR) were recorded in a NICOLET 510P spectrometer (Thermo Fisher Scientific, Waltham, MA, USA) with an attenuated total reflection accessory and a ZeSn as ATR crystal. Thermogravimetric (TG) analysis of the composites was obtained using a SHIMADZU TGA-50H thermobalance (Shimadzu Corporation, Japan) by heating the sample in air flow up to $950{ }^{\circ} \mathrm{C}$ with a heating rate of $20{ }^{\circ} \mathrm{C} \mathrm{min}-1$. The $\mathrm{N}_{2}$ adsorption-desorption isotherms at $-196^{\circ} \mathrm{C}$ were obtained using a Quadrasorb SI equipment (Quantachrome, Boston Beach, FL, USA). The samples were outgassed overnight at $110^{\circ} \mathrm{C}$ under high vacuum $\left(10^{-6} \mathrm{mbar}\right)$. The Brunauer-Emmett-Teller (BET) equation was applied to calculate the apparent surface area $\left(\mathrm{S}_{\mathrm{BET}}\right)$ [61,62], while the mesopore volume $\left(\mathrm{V}_{\text {meso }}\right)$ and total pore volume $\left(\mathrm{V}_{\text {total }}\right)$ were determined by applying the Barrett, Joyner, and Halenda $(\mathrm{BJH})$ method $[63,64]$ to the desorption branch of the $\mathrm{N}_{2}$ isotherms. The point of zero charge $\left(\mathrm{pH}_{\mathrm{PZC}}\right)$ of the materials was determined following the method described elsewhere $[65,66]$. The surface morphology of the synthesized photocatalysts was investigated by scanning electron microscopy (SEM) using a LEO (Carl Zeiss) GEMINI-1430-VP microscope (Oberkochen, Germany). Transmission electron microscopy (HRTEM) images were taken using a FEI Titan G2 60-300 microscope (FEI, Hillsboro, OR, USA) with a high brightness electron gun (X-FEG) operated at $300 \mathrm{kV}$ and equipped with a Cs image corrector (CEOS). The X-ray diffraction (XRD) patterns were obtained using a Philips PW 1710 diffractometer (Bruker, Rivas-Vacia, Madrid, Spain) provided with a CuK $\alpha$ radiation and a nickel filter that removes $\kappa \beta$ radiation. The average crystal size (D) of the samples was calculated by the Scherrer formula [67]:

$$
D=\frac{0.94 \lambda}{\beta \cos \theta}
$$

where $\lambda$ is the wavelength of the X-ray, $\beta$ is the FWHM (full-width at half-maximum) and $\theta$ is the diffraction angle. X-ray photoelectron spectroscopy (XPS) measurements were carried out using a Physical Electronics VersaProbe II apparatus (PHI, Chanhassen, MN, USA) equipped with a $\mathrm{MgK}_{\alpha} \mathrm{X}$-ray source $(h v=1486.6 \mathrm{eV})$ operating at $1.3 \mathrm{~V}$ and $20 \mathrm{~mA}$, and a hemispherical electron analyzer. Survey and multi-region spectra were recorded at the O1s and Zn2p photoelectron peaks. The optical properties of the photocatalysts were characterized by a UV-Vis spectrophotometer CARY 5E (VARIAN, Palo Alto, California, USA) equipped with a diffuse reflectance accessory (DRA. The band gap of the materials was calculated from the corresponding Tauc plots using (Abs.hv) $)^{1 / 2}$ units as a function of energy $(\mathrm{eV})$. 


\subsection{Photocatalytic Tests}

The photocatalytic performance of the prepared catalysts was evaluated for the degradation of vanillic acid, VA $\left(\mathrm{C}_{8} \mathrm{H}_{8} \mathrm{O}_{4}, 97 \%\right.$, Sigma-Aldrich, St. Louis, MO, USA) in aqueous solutions under both simulated solar irradiation and visible-LED at room temperature (average $25^{\circ} \mathrm{C}$ ). Solar irradiation was carried out using a SOLAR BOX 1500e (CO.FE.MEGRA, Milano, Italy) with a $1500 \mathrm{~W}$ Xenon lamp (500 $\mathrm{W} \mathrm{m}^{-2}$ of irradiance power). Irradiation with visible light was performed with an LED lamp from Oriel, model LSH-7320 LED Solar Simulator (Metrohm, Herisau, Switzerland), with a total power output of $110 \mathrm{~mW} \mathrm{~cm}{ }^{-2}$ and a wavelength range from 410 to $1100 \mathrm{~nm}$.

The photocatalytic experiments were performed in a glass reactor loaded with $50 \mathrm{~mL}$ of solution containing the model pollutant VA $\left(20 \mathrm{mg} \mathrm{L}^{-1}\right)$. The composite concentration was fixed as $1 \mathrm{~g} \mathrm{~L}^{-1}$ to avoid the effect of light scattering. The suspension was magnetically stirred and continuously purged with an oxygen flow. A dark period (30 min) was maintained before switching on the lamp in order to achieve the adsorption-desorption equilibrium conditions.

A syringe polyethersulfone (PES) filter of $0.45 \mu \mathrm{m}$ (Agilent Technologies, CA, USA) was used to separate the photocatalyst from the solution. The concentration of VA was determined by Ultra High-Performance Liquid Chromatography (UHPLC), using a Shimadzu Corporation apparatus (model Nexera, Tokyo, Japan) equipped with a Pump LC-30AD, an Autosampler SIL-30AC, an Oven CTO-20AC, a Degasser DGU-20A5r, a System Controller CBM-20 A Lite, and a Diode Array Detector (SPD-M20A). Chromatographic separation was optimized using a Shim-pack GISS-HP C18 $3 \mu \mathrm{m}$ column $(100 \times 3.0 \mathrm{~mm}$ I.D. $)$ supplied by Shimadzu Corporation (Tokyo, Japan). The temperature of the column oven and autosampler were set at $40^{\circ} \mathrm{C}$ and $15^{\circ} \mathrm{C}$, respectively, while the injection volume was $20 \mu \mathrm{L}$. The mobile phase consisted of a mixture of acetonitrile, water, and acetic acid (29:70:1), respectively, at isocratic conditions and with a flow rate of $1 \mathrm{~mL} \mathrm{~min}{ }^{-1}$.

The total organic carbon (TOC) content of initial and final samples was determined at the end of the experiments (i.e., 60 and $180 \mathrm{~min}$ for simulated solar light and visible-LED, respectively) using a TOC-5000A apparatus (Shimadzu, Kyoto, Japan).

The photocatalytic degradation was calculated using the following equation:

$$
[V A]=[V A]_{0} \times e^{-k_{a p} \times t}
$$

where $k_{a p}$ is the pseudo-first order kinetic constant, $t$ is the reaction time, and $[V A]_{0}$ and [VA] denote the pollutant concentration at $t=0$ and $t=\mathrm{t}$, respectively. The values of $k_{a p}$ were obtained by non-linear regression.

The photocatalytic degradation pathway of VA was studied using ethylenediaminetetraacetic acid (EDTA, $1.0 \mathrm{mM}$ ), furfuryl alcohol (FFA, $1.0 \mathrm{mM})$, and methanol $(\mathrm{MeOH}$, $1.0 \mathrm{mM})$ and as hole, singlet oxygen $\left({ }^{1} \mathrm{O}_{2}\right)$, and radical scavengers, respectively [58].

\section{Results and Discussion}

\subsection{Materials Characterization}

The GO content in the composites was verified by thermogravimetric analysis (TG). Figure 1 shows the thermogravimetric analysis (TG) under air flow for $\mathrm{GO}$ and $\mathrm{ZnO}$, as well as for the composites. The GO content of the composites was determined by burning in TG experiments, which directly analyze the weight loss along the combustion of GO in the composite (Figure 1). The results indicate a weight loss of 1.8, 2.8, 5.5, and $6.5 \mathrm{wt} . \%$ which is in agreement with the nominal GO content of the composites (i.e., 2.0, 3.0, 5.0, and $7.0 \mathrm{wt} . \%$., respectively). Taking into account the obtained weight loss, the composites were labelled as $\mathrm{ZnO}-\mathrm{GO} 1.8, \mathrm{ZnO}-\mathrm{GO} 2.8$, $\mathrm{ZnO}-\mathrm{GO} 5.5$, and $\mathrm{ZnO}-\mathrm{GO} 6.5$ for GO loading of $1.8,2.8,5.5$ and, $6.5 \mathrm{wt} . \%$, respectively. For GO, the weight loss observed up to ca. $500{ }^{\circ} \mathrm{C}$ should be attributed to the removal of oxygenated surface groups of GO, followed by the carbon combustion, as previously reported in the literature. [58,68]. Regarding the TG of composites, the carbon combustion occurs at lower temperatures (i.e., $<500{ }^{\circ} \mathrm{C}$ ). These 
results suggest that the presence of $\mathrm{ZnO}$ in the composites could have a catalytic effect on the combustion of the GO.

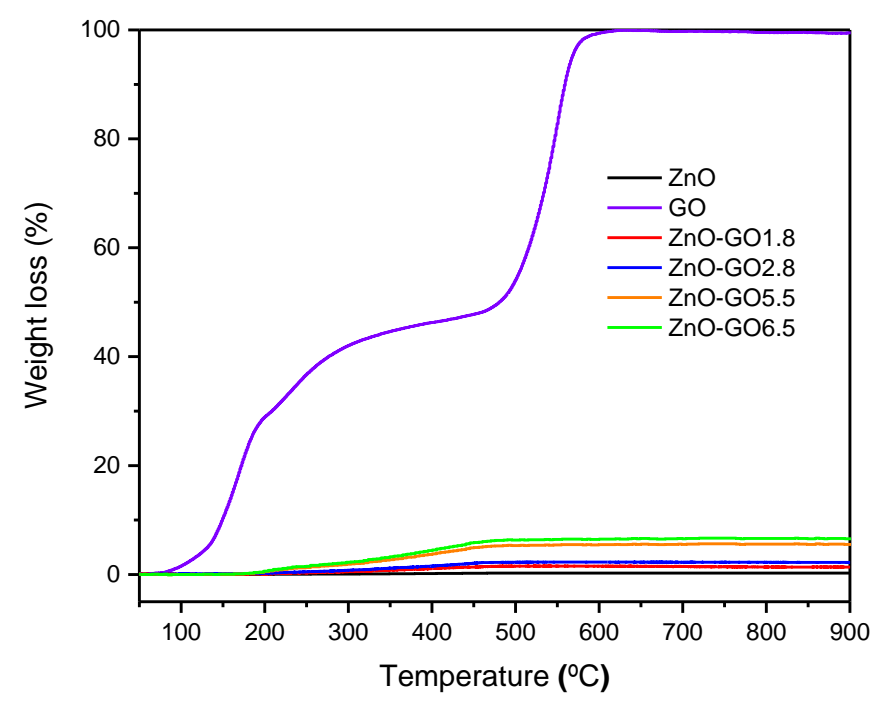

Figure 1. Thermogravimetric analysis in air of GO, pristine $\mathrm{ZnO}$, ZnO-GO1.8, ZnO-GO2.8, ZnOGO5.5, and ZnO-GO6.5 composites.

The textural characterization of pristine $\mathrm{ZnO}$ and the corresponding composites was studied by physisorption of $\mathrm{N}_{2}$ at $-196^{\circ} \mathrm{C}$. Figure 2 shows the $\mathrm{N}_{2}$ adsorption-desorption isotherms of the prepared materials. In general, the isotherms can be classified as type-II, in accordance with IUPAC classification. These results indicate the samples consist of macroporous materials, or materials with a low porosity [60]. In fact, the $\mathrm{N}_{2}$ volume is negligible as a consequence of the absence of micropores at a very low relative pressure. However, a large amount of $\mathrm{N}_{2}$ is adsorbed at high relative pressures due to the presence of large mesopores. In addition, all isotherms presented a small hysteresis loop of type H3, typical of agglomerates formed by platelets or adsorbents with slit-shaped pores, which could correspond to GO layers coated by $\mathrm{ZnO}$ particles.
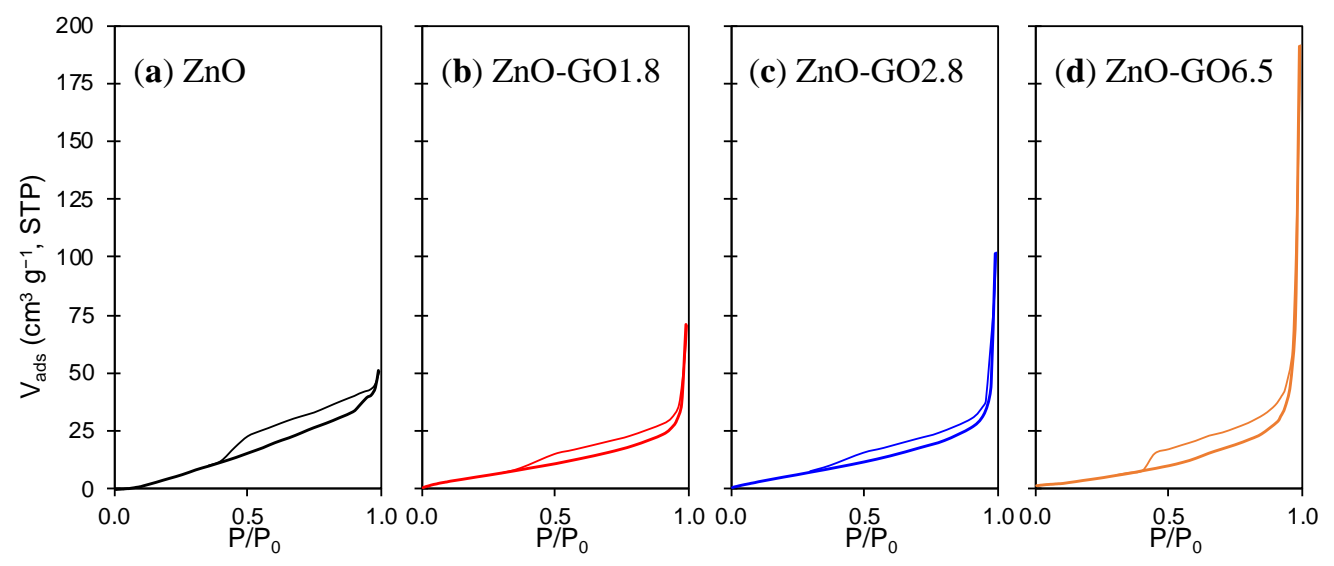

Figure 2. $\mathrm{N}_{2}$ adsorption-desorption isotherms of (a) pristine $\mathrm{ZnO}$, (b) $\mathrm{ZnO}-\mathrm{GO} 1.8$, (c) $\mathrm{ZnO}-\mathrm{GO} 2.8$ and (d) $\mathrm{ZnO}-G 06.5$.

Apparent surface areas $\left(S_{\mathrm{BET}}\right)$ of all prepared materials were between 10 and $19 \mathrm{~m}^{2} \mathrm{~g}^{-1}$, with $\mathrm{ZnO}-\mathrm{GO}$ composites usually presenting higher $S_{\mathrm{BET}}$ than pristine $\mathrm{ZnO}$ (e.g., 12 and $18 \mathrm{~m}^{2} \mathrm{~g}^{-1}$ for pristine $\mathrm{ZnO}$ and $\mathrm{ZnO}-\mathrm{GO} 5.5$, respectively, Table 1). In general, the addition of GO improved the porosity of the composites, namely the mesoporore volume ( $\left.V_{\text {meso }}\right)$ and the total pore volume $\left(V_{\text {total }}\right)$, these parameters generally increasing as the GO loading increased (e.g., $V_{\text {total }}=0.10$ and $0.29 \mathrm{~cm}^{3} \mathrm{~g}^{-1}$ for ZnO-GO1.8 and ZnO-GO6.5, respectively). 
This improvement in composites' porosity should be attributed to the intercalation of GO layers with $\mathrm{ZnO}$ particles generating new interstitial spaces in the mesopore range.

Table 1. BET surface area $\left(\mathrm{S}_{\mathrm{BET}}\right)$, mesopore volume $\left(\mathrm{V}_{\text {meso }}\right)$, total pore volume $\left(\mathrm{V}_{\mathrm{pore}}\right)$, $\mathrm{pH}$ at the point of zero charge $\left(\mathrm{pH}_{\mathrm{PZC}}\right)$, band-gap energy $\left(\mathrm{E}_{\mathrm{g}}\right)$ of materials, and crystallite size of synthetized materials.

\begin{tabular}{|c|c|c|c|c|c|c|}
\hline Samples & $\begin{array}{c}S_{\mathrm{BET}} \\
\left(\mathrm{m}^{2} \mathrm{~g}^{-1}\right)\end{array}$ & $\begin{array}{c}V_{\text {meso }} \\
\left(\mathrm{cm}^{3} \mathrm{~g}^{-1}\right)\end{array}$ & $\begin{array}{c}V_{\text {total }} \\
\left(\mathrm{cm}^{3} \mathrm{~g}^{-1}\right)\end{array}$ & $\mathrm{pH}_{\mathrm{PZC}}$ & $\begin{array}{c}E_{g} \\
(e V)\end{array}$ & $\begin{array}{c}\text { Crystallite Size } \\
(\mathrm{nm})\end{array}$ \\
\hline GO & 21 & n.d. & n.d. & 2.8 & - & n.d. \\
\hline $\mathrm{ZnO}$ & 12 & 0.07 & 0.07 & 7.6 & 3.12 & 41 \\
\hline $\mathrm{ZnO}-\mathrm{GO} 1.8$ & 19 & 0.09 & 0.10 & 7.4 & 3.05 & 36 \\
\hline $\mathrm{ZnO}-\mathrm{GO} 2.8$ & 18 & 0.08 & 0.09 & 7.4 & 3.05 & 34 \\
\hline ZnO-GO5.5 & 18 & 0.13 & 0.15 & 7.3 & 2.98 & 35 \\
\hline $\mathrm{ZnO}-\mathrm{GO} 6.5$ & 10 & 0.23 & 0.29 & 7.3 & 2.95 & 35 \\
\hline
\end{tabular}

n.d. = not determined.

The $\mathrm{pH}_{\mathrm{PCZ}}$ for $\mathrm{ZnO}, \mathrm{GO}$ and the composites are listed in Table 1. The $\mathrm{pH}_{\mathrm{PZC}}$ value of GO was 2.9, indicating the strong acidic character of the GO surface due to the presence of a large amount of oxygenated groups (mainly epoxy and hydroxyl groups) [69]. pH $\mathrm{PZC}_{\text {C }}$ could change depending on the synthesis method and structure of $\mathrm{ZnO}$ [70]. In this study, the $\mathrm{pH}_{\mathrm{PZC}}$ for $\mathrm{ZnO}$ was calculated to be approximately 7.6, indicating the neutral/slightly basic character of the semiconductor. The results point out that the $\mathrm{pH}$ PZC values for $\mathrm{ZnO}-\mathrm{GO}$ composites decrease as the GO content increases, resulting in materials with a slightly lower basic character than pristine $\mathrm{ZnO}$ [69].

Figure 3a shows the XRD patterns of $\mathrm{ZnO}$ nanoparticles and the $\mathrm{ZnO}-\mathrm{GO}$ composites. The similar patterns obtained denote that the crystalline structure of bare $\mathrm{ZnO}$ is maintained in the composites, as reported elsewhere $[37,42]$. Peaks observed at $31.9^{\circ}, 34.5^{\circ}, 36.3^{\circ}, 47.6^{\circ}$, $56.6^{\circ}, 62.9^{\circ}, 66.5^{\circ}, 68.0^{\circ}$, and $69.3^{\circ}$ correspond to the (100), (002), (101), (102), (110), (103), (200), (112), and (201) planes of the hexagonal ZnO wurtzite structure (JCPDS No. 36-1451), respectively $[35,37]$. Moreover, the characteristic peak of GO at approximately at $12^{\circ}$, and associated to the reflection for the (001) plane of GO, is not observed in the XRD patterns, due to the low content of GO present in the composites, as well as to the strong diffractions of $\mathrm{ZnO}$ that could mask the peak associated to GO [42,44]. The particle size of the $\mathrm{ZnO}$ nanoparticles and the $\mathrm{ZnO}$ composites were calculated using the Scherrer's equation and the results are included in Table 1. Particles sizes of 41, 36, 34, 35, and $35 \mathrm{~nm}$ were calculated for $\mathrm{ZnO}, \mathrm{ZnO}-\mathrm{GO} 1.8, \mathrm{ZnO}-\mathrm{GO} 2.8$, ZnO-GO5.5, and $\mathrm{ZnO}-\mathrm{GO} 6.5$ photocatalysts, respectively. In general, all the materials showed similar particles size values.
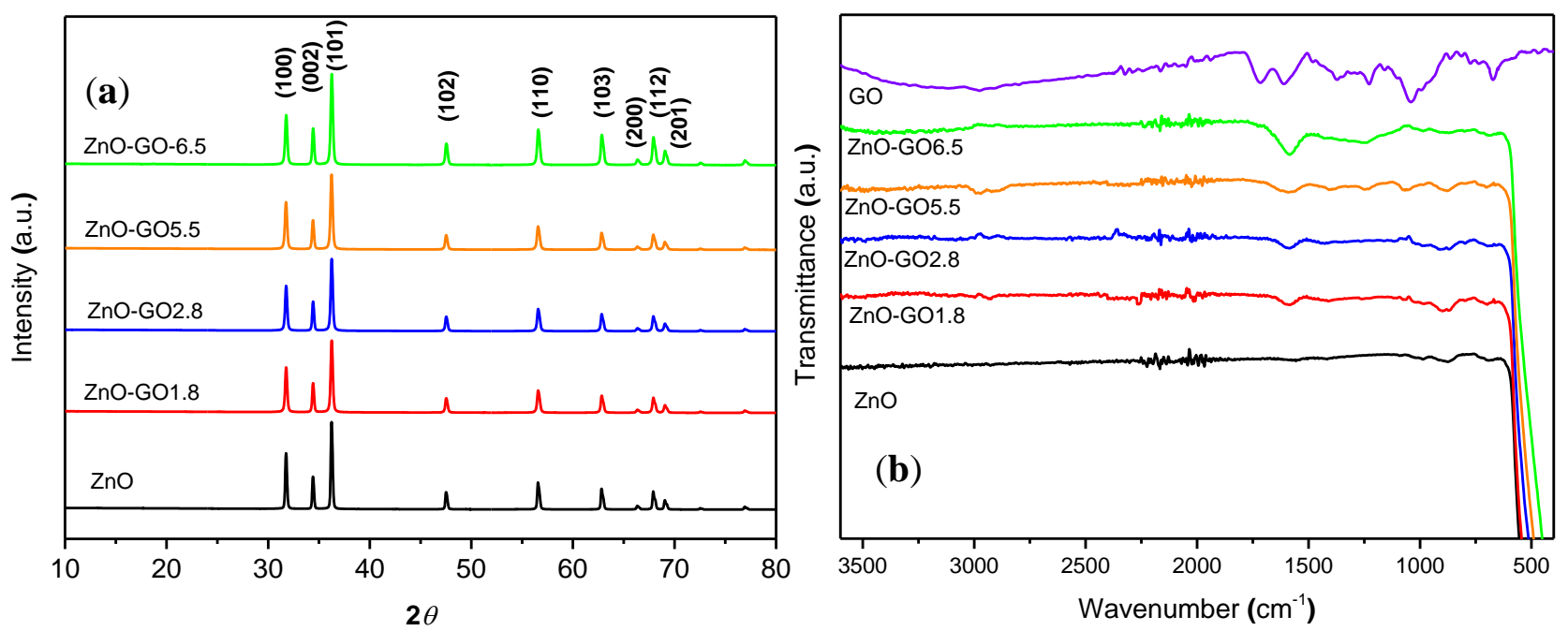

Figure 3. (a) XRD patterns of $\mathrm{ZnO}$ and $\mathrm{ZnO}-\mathrm{GO}$ composites, (b) FTIR spectra of GO, $\mathrm{ZnO}$ and $\mathrm{ZnO}-\mathrm{GO}$ composites. 
ATR-IR spectra of pristine $\mathrm{ZnO}, \mathrm{GO}$ and $\mathrm{ZnO}-\mathrm{GO}$ composites are depicted in Figure 3b. GO spectrum shows the main characteristic bands associated to the presence of oxygen functionalities at around 1050, 1350, and 1720, and a broad band ca. at 3000-3400 cm -1 attributed to $\mathrm{C}-\mathrm{O}, \mathrm{C}-\mathrm{OH}$ (stretching), $\mathrm{C}=\mathrm{O}$, and $\mathrm{C}-\mathrm{OH}$ (vibration) groups, respectively [64]. The spectra of $\mathrm{ZnO}$ and the composites show a common high intensity band at around $450-500 \mathrm{~cm}^{-1}$, corresponding to the stretching vibration of $\mathrm{Zn}-\mathrm{O}$ [71]. In general, the IR-spectra of the $\mathrm{ZnO}-\mathrm{GO}$ composites also show two weak bands at around $1600 \mathrm{~cm}^{-1}$ and $850 \mathrm{~cm}^{-1}$, attributed to the bending vibration of water and to the $\mathrm{Zn}-\mathrm{OH}$ group, respectively [71-73]. It is interesting to note that the intensity of the peaks associated to carbonyl groups $(\mathrm{C}=\mathrm{O})$ and epoxy groups $(\mathrm{C}-\mathrm{O})$ at around 1700 and $1100 \mathrm{~cm}^{-1}$, respectively, decreased significantly for the $\mathrm{ZnO}-\mathrm{GO}$ composites. These results indicate that the anchoring of $\mathrm{ZnO}$ to $\mathrm{GO}$ could be preferentially through these groups.

The SEM images of $\mathrm{ZnO}$ and $\mathrm{ZnO}-\mathrm{GO} 1.8, \mathrm{ZnO}-\mathrm{GO} 5.5$, and $\mathrm{ZnO}-\mathrm{GO} 6.5$ are depicted in Figure $4 \mathrm{a}-\mathrm{f}$ ( $\mathrm{ZnO}$ and $\mathrm{ZnO}-\mathrm{GO} 6.5$ are shown for two different magnifications). The $\mathrm{ZnO}$ structure consists of rod-like particles with size of $\sim 100 \mathrm{~nm}$ and spherical-like particles with ca. $50 \mathrm{~nm}$ of diameter (Figure $4 \mathrm{a}, \mathrm{b}$ ). In general, $\mathrm{ZnO}-\mathrm{GO}$ composites show more aggregated structures in comparison with pristine $\mathrm{ZnO}$, originating larger particle clusters and progressively favouring the formation of flat structures. The formation of $\mathrm{ZnO}$ nanoparticles from acetate/nitrate, forming from nanorods to nanoflakes, or grouped forming flower-like structures, depend on the experimental conditions, as previously described [72]. The composite micrographs (Figure $4 \mathrm{c}-\mathrm{f}$ ) do not show GO sheets uncoated with $\mathrm{ZnO}$, indicating a good assembly between $\mathrm{ZnO}$ and $\mathrm{GO}$ phases for all the composites prepared.

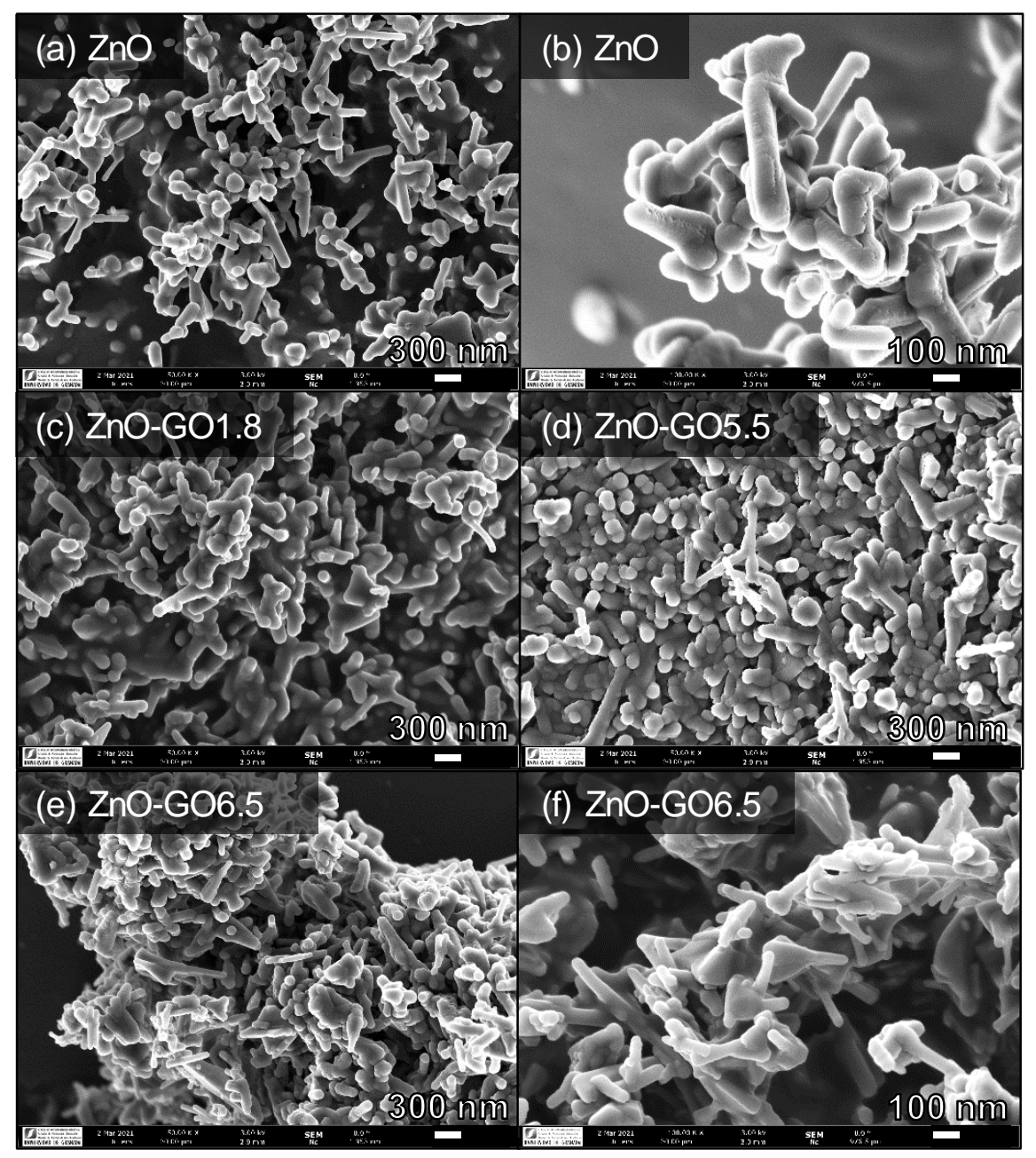

Figure 4. SEM micrographs of (a,b) ZnO, (c) ZnO-GO1.8, (d) ZnO-GO5.5, and (e,f) ZnO-GO6.5. 
Figure 5 shows HRTEM images of pristine $\mathrm{ZnO}$ and several $\mathrm{ZnO}-\mathrm{GO}$ composites. In general, $\mathrm{ZnO}$ consists of rod-like nanoparticles with a uniform size distribution and clear crystalline structure. Regarding the $\mathrm{ZnO}-\mathrm{GO}$ composites, micrographs reveal the presence of GO in the composites in the form of aggregated sheet-like structures. The HRTEM images (Figure 5b-d) also show a uniform distribution of the GO between the $\mathrm{ZnO}$ structures, inducing a good contact between the two phases. SAED images for selected samples allowed us to corroborate the polycrystalline character of $\mathrm{ZnO}$ particles with some of them highly ordered (inset-Figure 5b), and others with several overlapping planes (hkl) corresponding to different nanocrystals (inset-Figure $5 \mathrm{~d}$ ).

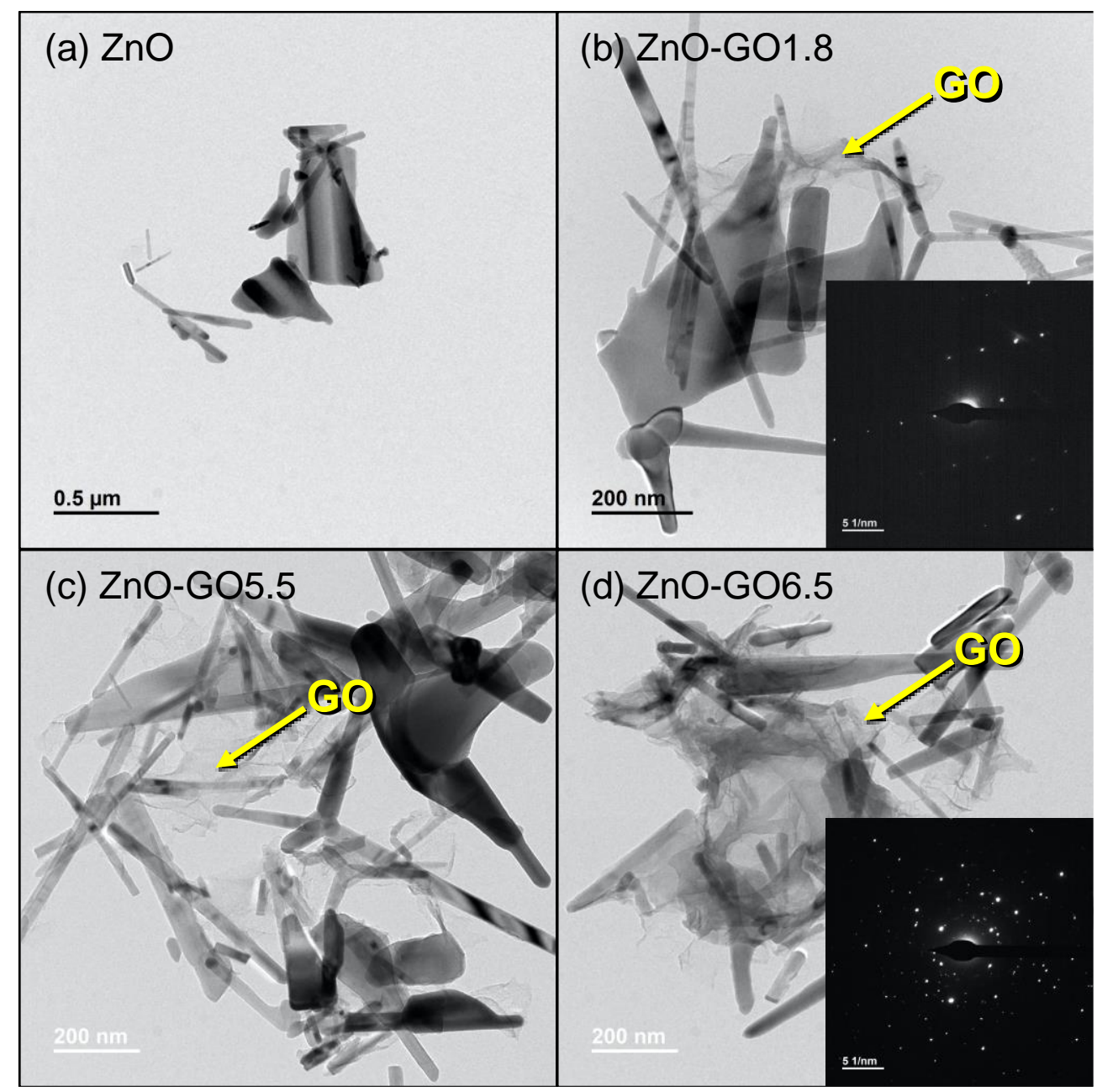

Figure 5. HRTEM micrographs of (a) ZnO, (b) ZnO-GO1.8, (c) ZnO-GO5.5, and (d) ZnO-GO6.5. Selected areas electron diffraction (SAED) images are included as insets.

The chemical composition of $\mathrm{ZnO}$ and the $\mathrm{ZnO}-\mathrm{GO}$ composites was studied by XPS, the results corresponding to the analysis for the $\mathrm{O} 1 \mathrm{~s}$ and $\mathrm{Zn} 2 \mathrm{p}$ regions shown in Figure $6 \mathrm{a}, \mathrm{b}$, respectively. The O1s spectra of the materials were deconvoluted into three components, the first peak placed at $\sim 529.8 \mathrm{eV}$ is assigned to $\mathrm{O}_{2}{ }^{-}$ions from $\mathrm{Zn}-\mathrm{O}$ bonds belonging to the $\mathrm{ZnO}$ wurtzite structure, while the second one at $\sim 530.8 \mathrm{eV}$ corresponds to $\mathrm{OH}$ groups absorbed onto the $\mathrm{ZnO}$ surface [74], and double-bonded oxygen $(\mathrm{C}=\mathrm{O})$ of oxygencontaining groups anchored in the GO structure [75]. The last peak of the O1s region located $\sim 531.8 \mathrm{eV}$ can be ascribed to single-bonded oxygen $(\mathrm{C}-\mathrm{O})$ from the oxygen functionalities of GO, in particular alcohol, ether, and epoxy groups [75]. The detected carbon for the $\mathrm{ZnO}$ sample could be related to the carbon adsorbed on its surface during the exposure of the sample to the ambient atmosphere [74]. 

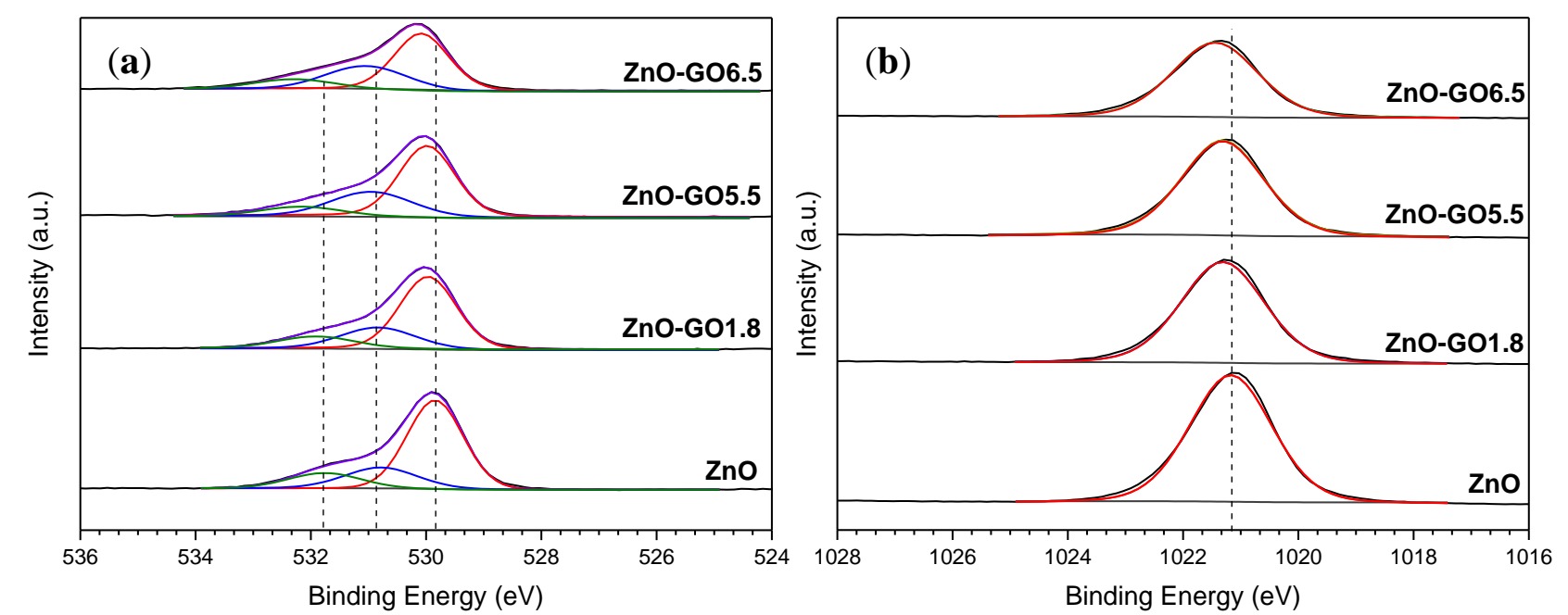

Figure 6. XPS spectra and deconvolution of (a) O1s and (b) Zn2p regions of $\mathrm{ZnO}$ and selected $\mathrm{ZnO}-\mathrm{GO}$ composites. (The $\mathrm{Zn} 2 \mathrm{p}_{3 / 2}$ region was only represented for clarification).

Regarding the Zn2p region, two peaks were located at $\sim 1021.2$ and $\sim 1044.2 \mathrm{eV}$, attributed to $Z n 2 p_{3 / 2}$ and $Z n 2 p_{1 / 2}$, respectively, and a binding energy (B.E.) difference of $23.0 \mathrm{eV}$ [74]. The XPS spectra of $\mathrm{Zn} 2 \mathrm{p}$ region for the different materials only showed a clear peak at $\sim 1021.2 \mathrm{eV}$, which denotes a $\mathrm{Zn}^{2+}$ oxidation state. For $\mathrm{ZnO}-\mathrm{GO}$ composites with larger $\mathrm{GO}$ contents, a shifted $\mathrm{Zn} 2 \mathrm{p}_{3 / 2}$ peak towards a higher B.E was observed, due to the chemical environment interaction between $\mathrm{ZnO}$ particles and $\mathrm{GO}$ functionalities.

UV-Vis diffuse reflectance spectra were carried out in order to determine the electronic properties of pristine $\mathrm{ZnO}$ and their composites. For all the photocatalysts, a strong intense absorption band in the UV range with onset at $<400 \mathrm{~nm}$ was observed (Figure 7a) This band is associated to the intrinsic band-gap absorption of pristine $\mathrm{ZnO}$ [35]. It can be seen that the absorption intensity of the composites is significantly improved in the visible region due to the presence of GO $[35,37,44]$. In general, this effect is proportional with the different GO loading on the composites, obtaining a stronger absorption capacity in the visible region for the composites with a higher amount of GO (i.e., ZnO-GO5.5 and ZnO-GO6.5). This effect can be attributed to the capacity of carbon materials to absorb light as well as to the creation of electronic interactions between carbon and $\mathrm{ZnO}$ as reported in the literature for the case of other carbon and metal oxide phases $[38,60,76]$. Figure $7 \mathrm{~b}$ shows the Tauc's plots versus the energy $(\mathrm{eV})$. The calculated $\mathrm{E}_{\mathrm{g}}$ of $\mathrm{ZnO}, \mathrm{ZnO}-\mathrm{GO} 1.8, \mathrm{ZnO}-\mathrm{GO} 2.8, \mathrm{ZnO}-\mathrm{GO}$.5, and $\mathrm{ZnO}-\mathrm{GO} 6.5$ were 3.12, 3.05, 3.05, 2.98, and $2.95 \mathrm{eV}$, respectively (Table 1), being the obtained band gap for the composites lower than the value obtained for pristine $\mathrm{ZnO}$.

\subsection{Photocatalytic Activity of the $\mathrm{ZnO}-\mathrm{GO}$ Composites}

The photocatalytic efficiency of $\mathrm{ZnO}$ and $\mathrm{ZnO}-\mathrm{GO}$ composites (with different GO loading) for VA degradation under simulated solar light and visible-LED are shown in Figure $8 \mathrm{a}, \mathrm{b}$, respectively. The kinetic rate constant for solar light $\left(k_{a p}\right)$, the VA conversion $\left(X_{V A}(\%)\right)$, and TOC removal $\left(X_{T O C}(\%)\right)$ for both solar light and visible-LED are gathered in Table 2. The experiment in the absence of a photocatalyst (i.e., photolysis) shows a null degradation of the contaminant under both solar light (Figure 8a) and visible-LED (not shown). On the other hand, the adsorption equilibrium in dark conditions was established after $60 \mathrm{~min}$ for $\mathrm{ZnO}$ and $\mathrm{ZnO}-\mathrm{GO}$ composites, with obtained values of approximately $3-8 \%$ of the initial VA concentration. For all the photocatalysts tested, 60 min was proven to be enough to reach the adsorption equilibrium. 

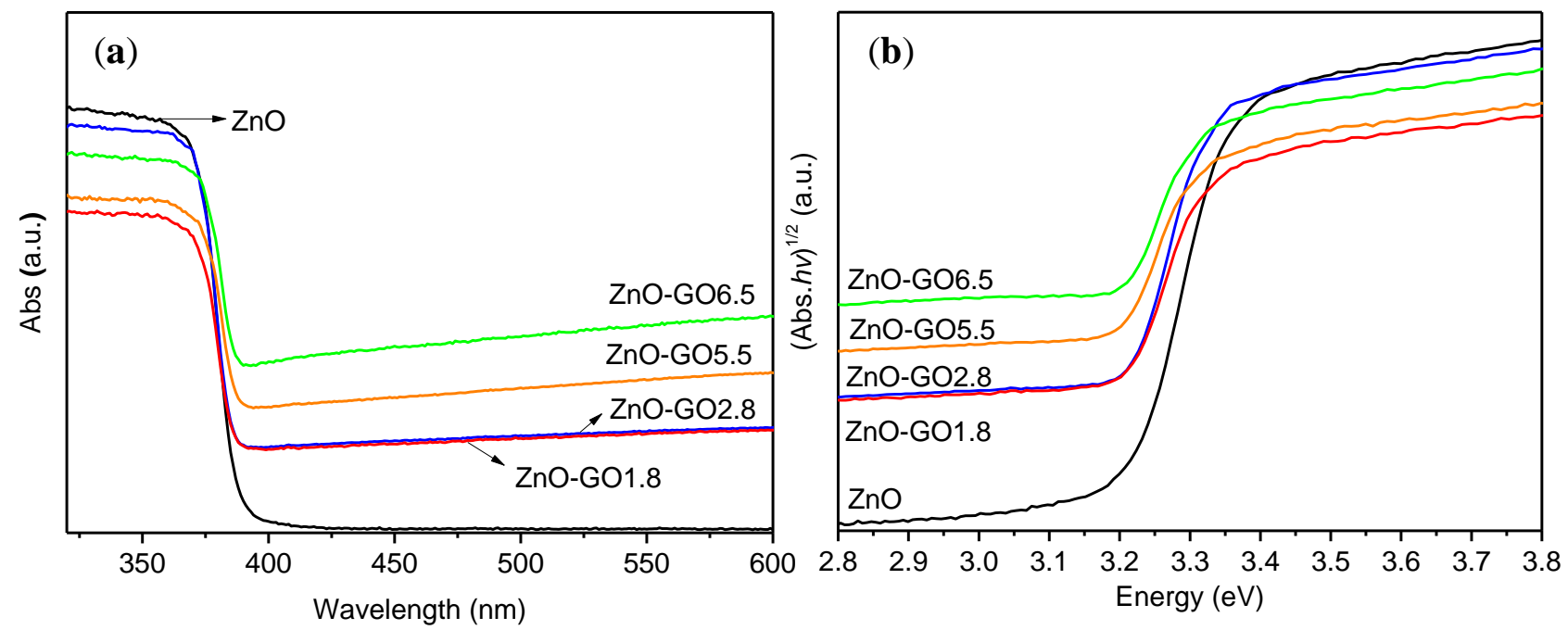

Figure 7. (a) UV-vis spectra and (b) Tauc's plots versus the energy in eV of $\mathrm{ZnO}$ and $\mathrm{ZnO}-\mathrm{GO}$ composites.
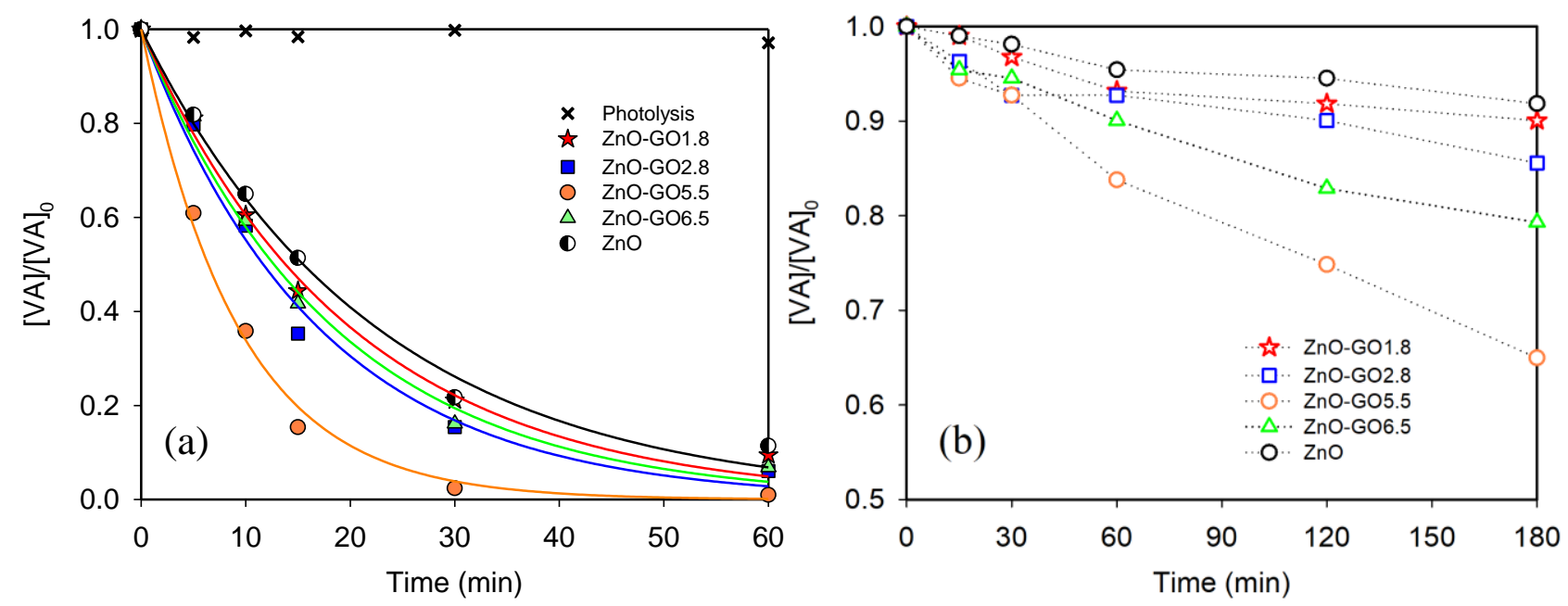

Figure 8. Photocatalytic degradation of VA as a function of time for $\mathrm{ZnO}$ and the $\mathrm{ZnO}-\mathrm{GO}$ composites under (a) simulated solar light and (b) visible-LED.

Table 2. VA conversion $\left(\mathrm{X}_{\mathrm{VA}}\right)$, TOC removal (\%), pseudo-first order kinetic rate constant $\left(\mathrm{k}_{\mathrm{ap}}\right)$, and regression coefficient $\left(\mathrm{r}^{2}\right)$ under simulated solar light and visible-LED.

\begin{tabular}{|c|c|c|c|c|c|c|c|c|}
\hline \multirow[b]{2}{*}{ Sample } & \multicolumn{4}{|c|}{ Simulated Solar Light (60 Min) } & \multicolumn{4}{|c|}{ Visible-LED (180 Min) } \\
\hline & $\begin{array}{l}X_{V A} \\
(\%)\end{array}$ & $\begin{array}{c}k_{a p} \\
\left(10^{-3} \min ^{-1}\right)\end{array}$ & $\mathbf{r}^{2}$ & $\begin{array}{c}X_{T O C} \\
(\%)\end{array}$ & $X_{T O C} / X_{V A}$ & $\begin{array}{l}X_{V A} \\
(\%)\end{array}$ & $\begin{array}{c}X_{T O C} \\
(\%)\end{array}$ & $X_{T O C} / X_{V A}$ \\
\hline Photolysis & 2.8 & - & - & - & - & - & - & - \\
\hline $\mathrm{ZnO}$ & 85.9 & $44.7 \pm 2$ & 0.992 & 25.9 & 0.302 & 8.1 & 3.2 & 0.395 \\
\hline $\mathrm{ZnO}-\mathrm{GO} 1.8$ & 90.5 & $50.2 \pm 2$ & 0.993 & 30.5 & 0.337 & 9.9 & 5.5 & 0.555 \\
\hline $\mathrm{ZnO}-\mathrm{GO} 2.8$ & 93.9 & $59.4 \pm 4$ & 0.988 & 38.9 & 0.414 & 14.4 & 8.1 & 0.563 \\
\hline $\mathrm{ZnO}-\mathrm{GO} 5.5$ & 99.0 & $100.8 \pm 5$ & 0.995 & 57.5 & 0.581 & 35.0 & 20.1 & 0.574 \\
\hline $\mathrm{ZnO}-\mathrm{GO} 6.5$ & 93.1 & $54.6 \pm 3$ & 0.991 & 40.2 & 0.432 & 20.7 & 10.7 & 0.517 \\
\hline
\end{tabular}

Figure 8a shows a significant photocatalytic performance using all the prepared materials for the degradation of VA under solar light. The results indicate that the presence of GO in the composites enhances the degradation efficiency of pristine $\mathrm{ZnO}$ under solar light $\left(k_{a p}=100.8 \times 10^{-3} \mathrm{~min}^{-1}, 59.4 \times 10^{-3} \mathrm{~min}^{-1}, 54.6 \times 10^{-3} \mathrm{~min}^{-1}, 50.2 \times 10^{-3} \mathrm{~min}^{-1}\right.$, and $44.7 \times 10^{-3} \mathrm{~min}^{-1}$ for $\mathrm{ZnO}-G O 5.5, \mathrm{ZnO}-G O 2.8, \mathrm{ZnO}-G O 6.5, \mathrm{ZnO}-\mathrm{GO} 1.8$, and $\mathrm{ZnO}$, 
respectively). Regarding the results obtained under visible-LED (Figure 8b), a similar trend was observed for VA degradation, i.e., ZnO-GO5.5 (35\%) > ZnO-GO6.5 (20.7\%) > $\mathrm{ZnO}-\mathrm{GO} 2.8(14.4 \%)>\mathrm{ZnO}-\mathrm{GO} 1.8(9.9 \%)>\mathrm{ZnO}(8.1 \%)$, where the values in brackets are the VA conversion (Table 2). As expected, the VA degradation under visible-LED was lower than that obtained under simulated solar irradiation as there is no UV irradiation, and only photons with $\lambda>430 \mathrm{~nm}$ can reach the samples. For all the photocatalysts tested, the results indicate that the presence of GO enhances the photocatalytic activity under both solar irradiation and visible-LED as previously reported $[42,44,77,78]$. The possible reasons for higher photocatalytic activity of the $\mathrm{ZnO}-\mathrm{GO}$ composites compared to pristine $\mathrm{ZnO}$ could mainly be ascribed to the increased adsorption capacity, as well as the extended light absorption in the visible range (Figure $7 a)[77,78]$. Moreover, considering the conduction band of pristine $\mathrm{ZnO}$ (c.a. $-4.05 \mathrm{eV}$ ) [79] and work function of graphene (c.a. $-4.42 \mathrm{eV}$ ) [80], the direct transfer of photogenerated electrons between $\mathrm{ZnO}$ and GO could be favorable. This electron transfer might hinder the electron-hole recombination, enhancing the photocatalytic performance under solar irradiation and visible light as previously observed [78,81].

It is noteworthy that amongst all the prepared materials, the composite containing 5.5 wt.\% of GO, i.e., ZnO-GO5.5 exhibits not only the best catalytic activity but also the highest TOC removal in comparison with all other composites under solar irradiation and visible-LED (i.e., 57.5 and $20.1 \%$, respectively, Table 2). These results point out the relevance to select the adequate carbon content in the carbon-semiconductor composites in order to obtain the optimal catalytic performance, as previously reported for other graphene-metal oxide composites $[58,60]$. However, the lower photocatalytic activity observed for the composite containing a GO loading higher than the optimum value (i.e., ZnO-GO6.5 vs. $\mathrm{ZnO}-\mathrm{GO} 5.5$ ) could be associated with the scattering effect of GO [77], or the formation of larger aggregates, as shown by SEM (Figure 4), that could hinder the interactions with the irradiation.

In order to evaluate the mineralization under both solar light and visible-LED, the ratio of TOC removal $\left(X_{T O C}\right)$ and VA degradation $\left(X_{V A}\right)$ was introduced in Table 2. In spite of the lower activity obtained under visible-LED compared to solar light (due to the lower extent of the emission spectra), the results show that the experiments under LED illumination were more effective for the mineralization of VA as the ratio $\left(X_{T O C} / X_{V A}\right)$ was higher under visible-LED than that obtained under simulated solar light (Table 2). It is also noteworthy that this parameter varies according to the tendency previously observed for the photocatalytic activity, i.e., progressively increases with the increases in GO loading but decreases for GO contents higher than the optimum value (i.e., 6.5 wt.\%).

\subsection{Influence of Hole, Radical, and Non-Radical Scavengers and Study of the Stability}

The ZnO-GO5.5 composite was selected for a deep study using hole, radical, and non-radical scavengers, in particular ethylenediaminetetraacetic acid (EDTA), methanol $(\mathrm{MeOH})$, and furfuryl alcohol (FFA), respectively, in order to elucidate the possible reactive oxygen species (ROS) involved in the photodegradation of VA under simulated solar light and visible-LED (Figure 9a,b, respectively).

Figure 9a shows the degradation of VA in presence of the selected scavengers under simulated solar irradiation. The results show that all scavengers used decrease the VA degradation. In particular, this effect was more pronounced in the presence of EDTA and to a lesser extent by MEOH and FFA, obtaining a VA degradation of around 5, 81, and 97\%, respectively, compared to $99 \%$ with no scavenger. These results indicate that, although reactive radicals (formed from photoexcited electrons) and non-radical species (such as singlet oxygen, ${ }^{1} \mathrm{O}_{2}$ ) are involved in the reaction, the photogenerated holes seem to be the main responsible species in the degradation of VA (by direct oxidation or by formation of radicals such as $\mathrm{HO}^{\bullet}$ ) under simulated solar light. 

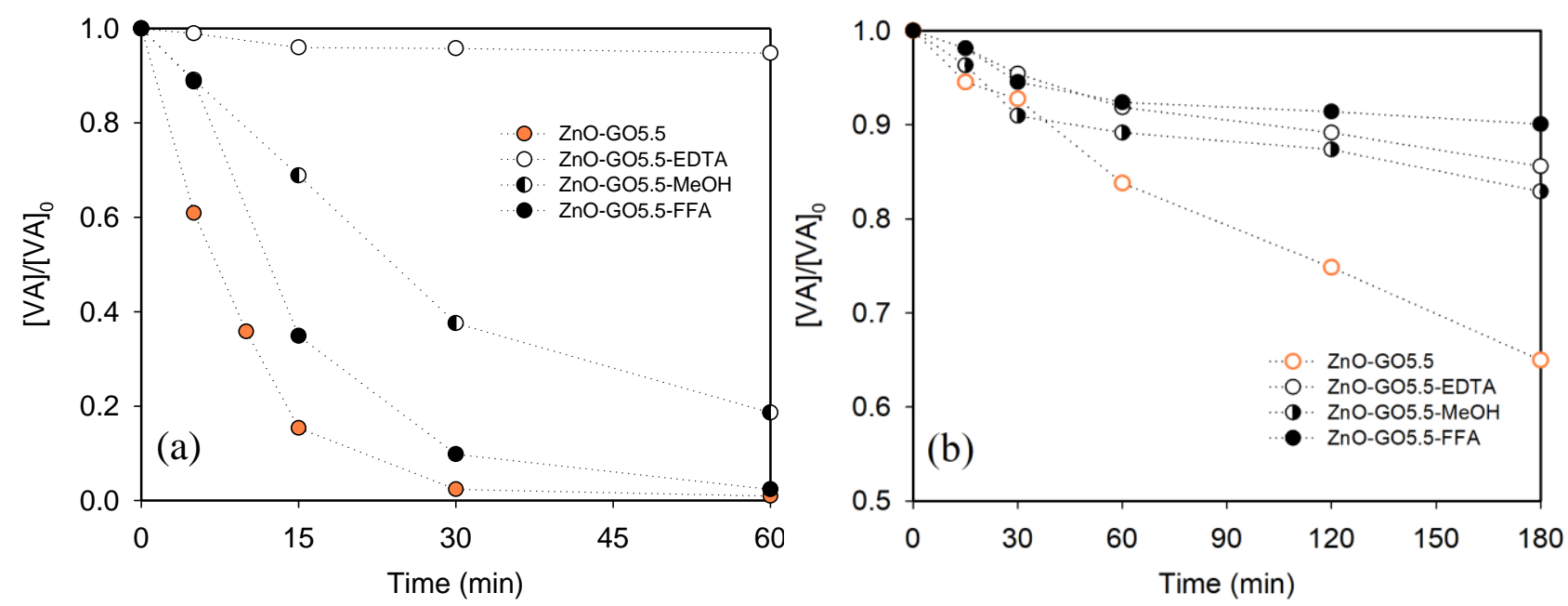

Figure 9. Effect of hole/radical/non-radical scavengers (EDTA/MeOH/FFA) on the photocatalytic degradation of VA using ZnO-GO5.5 under (a) simulated solar light and (b) visible-LED.

In the case of visible-LED (Figure 9b), the obtained results also suggest that hole, radical, and non-radical species participate in the reaction mechanism, however, the participation of non-radicals (singlet oxygen, ${ }^{1} \mathrm{O}_{2}$ ) in the photocatalytic mechanism seems to play a major representative role in the photocatalytic mechanism under visible-LED, as the degradation observed in presence of FFA was lower in comparison with that obtained for EDTA and $\mathrm{MeOH}$ (i.e. 10, 14, and 17\%, respectively). The formation of species such as hydroxyl radicals $\left(\mathrm{HO}^{\bullet}\right)$ and hydroperoxyl radicals $\left(\mathrm{HOO}^{\bullet}\right)$ under $\mathrm{UV}$ irradiation, as well as the formation of other species such as singlet oxygen $\left({ }^{1} \mathrm{O}_{2}\right)$ and superoxide anion $\left(\mathrm{O}_{2}{ }^{\bullet-}\right)$ under visible light, have been reported in the literature as active species during the degradation of contaminants in the aqueous phase using $\mathrm{ZnO}$ and other semiconductors [82-86]. These results show the different photocatalytic mechanisms involved in the degradation of water pollutants under simulated solar irradiation and visible illumination [87].

The photo-stability of photocatalysts is an important factor for industrial applications. Thus, one of the major drawbacks of $\mathrm{ZnO}$ is their severe photo-corrosion under $\mathrm{UV} / \mathrm{Vis}$ irradiation, which can result in a significant decrease in the photocatalytic activity in reused processes $[88,89]$. Pristine $\mathrm{ZnO}$ and $\mathrm{ZnO}-\mathrm{GO} 5.5$ were selected in order to evaluate its photocatalytic stability in several recycle runs under simulated solar light (i.e., UVVis) and visible-LED for $60 \mathrm{~min}$ and $180 \mathrm{~min}$, respectively (Figure 10). The experimental procedure was similar to that described in Section 2.3, but in this case after each reaction, the catalyst was rinsed with water and dried in an oven at $80^{\circ} \mathrm{C}$ for $5 \mathrm{~h}$ before reuse in two additional consecutive photocatalytic experiments. The photocatalytic activity of pristine $\mathrm{ZnO}$ decreased during the three consecutive cycles under solar and LED light. However, stability increased in the case of the composite, the conversion values decreasing slightly after the first cycle under both radiations (Figure 10). In fact, the VA conversion $\left(X_{V A}, \%\right)$ was lower in the second run in comparison with the first under both simulated solar light (i.e., from 99 to $80 \%$ ) and visible-LED (i.e., from 35 to 20\%), whereas the photocatalytic activity remained practically constant in the third run (75 and 18\% for solar light and visibleLED, respectively) for the composite. These results show that the $\mathrm{ZnO}-\mathrm{GO}$ composite was stable under solar irradiation and visible-LED, indicating that the photo-corrosion of $\mathrm{ZnO}$ could be reduced by the presence of GO. This fact highlights the stability and viability of the prepared $\mathrm{ZnO}-\mathrm{GO}$ composites to work under continuous mode in future studies. 


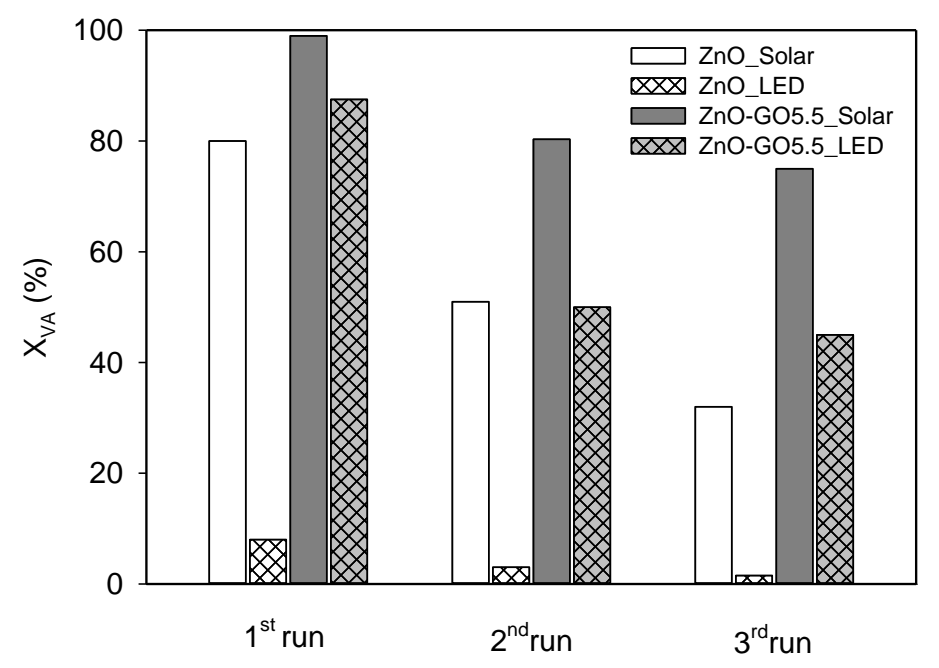

Figure 10. Photocatalytic performance of three consecutive cycles degradation for pristine $\mathrm{ZnO}$ and ZnO-GO5.5 under simulated solar light and visible-LED.

Table 3 comprises studies regarding different photocatalysts that have been recently published towards phenolic compounds degradation under UV/Vis light irradiation. It can be concluded that the obtained photocatalyst in this work showed a good photocatalytic performance and photostability compared to that of other materials reported in the literature.

Table 3. Compilation of recently published works regarding different photocatalysts for phenolic compounds degradation under UV/Vis light irradiation.

\begin{tabular}{|c|c|c|c|c|c|}
\hline Photocatalyt & Contaminant & Light Source & $\begin{array}{l}\text { Catalyst Loading } \\
\qquad\left(\mathrm{g} \mathrm{L}^{-1}\right)\end{array}$ & $\begin{array}{l}\text { Degradation } \\
(\%)\end{array}$ & Ref. \\
\hline Pd-based photocatalyst & $\begin{array}{c}\text { Phenol } \\
\left(20 \mathrm{mg} \mathrm{L}^{-1}\right)\end{array}$ & UV-Vis & 0.7 & 93.75 & [90] \\
\hline $\mathrm{TiO}_{2}$ & $\begin{array}{l}\text { Phenolic compounds } \\
\qquad(0.53 \mathrm{mM})\end{array}$ & UV & 1 & $>90$ & [91] \\
\hline $\mathrm{Au}-\mathrm{ZnO}$ nanomaterials & $\begin{array}{c}\text { Phenol, catechol and } \\
\text { hydroquinone }\left(25 \mathrm{mg} \mathrm{L}^{-1}\right)\end{array}$ & UV-Vis & 1 & $>85$ & [92] \\
\hline Nano- $\mathrm{TiO}_{2}$ & $\begin{array}{l}\text { Phenolic compounds } \\
\left(100 \mathrm{mg} \mathrm{L}^{-1}\right)\end{array}$ & UV & 1 & 97 & [93] \\
\hline rGO- $\mathrm{TiO}_{2}$ & $\begin{array}{l}\text { Phenol, p-chlorophenol and } \mathrm{p} \\
\text { nitrophenol }\left(20 \mathrm{mg} \mathrm{L}^{-1}\right)\end{array}$ & UV and Xenon & 0.1 & $\sim 60$ & {$[94]$} \\
\hline immobilized nano- $\mathrm{ZnO}$ & Phenol $\left(2 \mathrm{mg} \mathrm{L}^{-1}\right)$ & $\mathrm{UV}_{\mathrm{A}}$ & $10-25 \mathrm{~m}^{2} \mathrm{~g}^{-1}$ & 20 & [95] \\
\hline $\mathrm{ZnO} / \mathrm{TiO}_{2}-\mathrm{rGO}$ & Phenol (60 mg L $\left.{ }^{-1}\right)$ & 3 visible Cd lamps & 0.6 & 100 & [96] \\
\hline ZnO-Graphene & Phenol (40 mg L $\left.{ }^{-1}\right)$ & Solar radiation & 1 & $>90$ & [97] \\
\hline $\mathrm{ZnO}-\mathrm{GO}$ & Vanillic acid $\left(20 \mathrm{mg} \mathrm{L}^{-1}\right)$ & Xenon Lamp & 1 & 100 & This work \\
\hline $\mathrm{ZnO}-\mathrm{GO}$ & Vanillic acid (20 mg L $\left.{ }^{-1}\right)$ & LED visible & 1 & 35 & This work \\
\hline
\end{tabular}

\section{Conclusions}

Photocatalysts based on $\mathrm{ZnO}$ and GO were prepared with different GO contents. The results indicated a high photocatalytic efficiency for the degradation and mineralization of vanillic acid (VA) under simulated solar light and visible-LED $(\lambda>430 \mathrm{~nm})$. SEM images showed that pristine $\mathrm{ZnO}$ consisted of rod and spherical-like particles. For the composites, more aggregate structures (with the formation of flat assemblies) were observed. The presence of GO in the composites led to superior photocatalytic performance when compared to that obtained from pristine $\mathrm{ZnO}$ under solar light and visible-LED. Nevertheless, the highest catalytic performance was obtained with the composite comprising a GO content of $5.5 \mathrm{wt}$.\%, achieving a VA degradation of $99.0 \%$ under simulated solar light. Higher $X_{T O C} / X_{V A}$ ratios were obtained under LED light, indicating a more efficient mineralization of contaminant in comparison to that obtained under simulated solar light. 
The obtained results from the study of hole, radical, and non-radical scavengers suggested that the photogenerated holes seem to be the main responsible species in the degradation of VA under solar light. The participation of singlet oxygen $\left({ }^{1} \mathrm{O}_{2}\right)$ played a major representative role in the photocatalytic mechanism under visible-LED.

The most effective material, i.e., $\mathrm{ZnO}-\mathrm{GO} 5.5$, showed better photo-stability in three consecutive runs compared to pristine $\mathrm{ZnO}$, and only a slight decrease of VA degradation was observed under both solar irradiation and visible-LED.

Author Contributions: Conceptualization, L.M.P.-M. and S.M.-T.; methodology, N.M., Á.P.-M., F.J.M.-H. and S.M.-T.; investigation, N.M., Á.P.-M., L.M.P.-M. and S.M.-T.; writing—original draft preparation, N.M., Á.P.-M., L.M.P.-M. and A.S.; writing—review and editing, A.S., L.M.P.-M., F.J.M.H. and S.M.-T.; supervision, F.J.M.-H.; and funding acquisition, L.M.P.-M., S.M.-T. and F.J.M.-H. All authors have read and agreed to the published version of the manuscript.

Funding: This work was supported by the Spanish Project ref. RTI 2018-099224-B100 funded by ERDF/Ministry of Science, Innovation and Universities-State Research Agency and the Nano4Fresh project (ref. PCI2020-112045), as part of the PRIMA Programme supported by the European Union.

Acknowledgments: Á.P.-M. is grateful to Ministry of Science, Innovation and Universities for a FPI fellowship (ref. PRE2019-087946). L.M.P.-M. (RYC-2016-19347) and S.M.-T. (RYC-2019-026634I/AEI/10.13039/501100011033) acknowledge the Spanish Ministry of Economy and Competitiveness (MINECO), the State Research Agency and the European Social Found for their Ramón y Cajal research contracts. "Unidad de Excelencia Química Aplicada a Biomedicina y Medioambiente" of the University of Granada (UEQ-UGR) is gratefully acknowledged for the technical assistance. Shahid Beheshti University is appreciated for the partial support of the present study.

Conflicts of Interest: The authors declare no conflict of interest.

\section{References}

1. Comninellis, C.; Kapalka, A.; Malato, S.; Parsons, S.A.; Poulios, I.; Mantzavinos, D. Advanced oxidation processes for water treatment: Advances and trends for R\&D. J. Chem. Technol. Biotechnol. 2008, 83, 769-776. [CrossRef]

2. Priya, B.; Shandilya, P.; Raizada, P.; Thakur, P.; Singh, N.; Singh, P. Photocatalytic mineralization and degradation kinetics of ampicillin and oxytetracycline antibiotics using graphene sand composite and chitosan supported BiOCl. J. Mol. Catal. A Chem. 2016, 423, 400-413. [CrossRef]

3. Hussain, S.; Khan, A.J.; Arshad, M.; Javed, M.S.; Ahmad, A.; Shah, S.S.A.; Khan, M.R.; Akram, S.; Zulfiqar; Ali, S.; et al. Charge storage in binder-free 2D-hexagonal CoMoO4 nanosheets as a redox active material for pseudocapacitors. Ceram. Int. 2021, 47, 8659-8667. [CrossRef]

4. Hussain, S.; Yang, X.; Aslam, M.K.; Shaheen, A.; Javed, M.S.; Aslam, N.; Aslam, B.; Liu, G.; Qiao, G. Robust TiN nanoparticles polysulfide anchor for Li-S storage and diffusion pathways using first principle calculations. Chem. Eng. J. 2020, $391,123595$. [CrossRef]

5. DeVree, B.T.; Steiner, L.M.; Głazowska, S.; Ruhnow, F.; Herburger, K.; Persson, S.; Mravec, J. Current and future advances in fluorescence-based visualization of plant cell wall components and cell wall biosynthetic machineries. Biotechnol. Biofuels 2021, 14 . [CrossRef] [PubMed]

6. Liu, G.; Zhang, X.; Chen, X.; He, Y.; Cheng, L.; Huo, M.; Yin, J.; Hao, F.; Chen, S.; Wang, P.; et al. Additive manufacturing of structural materials. Mater. Sci. Eng. R Rep. 2021, 100596. [CrossRef]

7. Eray, E.; Candelario, V.M.; Boffa, V.; Safafar, H.; Østedgaard-Munck, D.N.; Zahrtmann, N.; Kadrispahic, H.; Jørgensen, M.K. A roadmap for the development and applications of silicon carbide membranes for liquid filtration: Recent advancements, challenges, and perspectives. Chem. Eng. J. 2021, 414. [CrossRef]

8. Xu, J.; Hong, C.; Geng, J.; Jin, X.; Pan, Y.; Wang, H.; Luo, X.; Zhang, X. Facile synthesis, mechanical toughening, low thermal conductivity and fire-retardant of lightweight quartz fiber reinforced polymer nanocomposites. Compos. Sci. Technol. $2021,211$. [CrossRef]

9. Chen, X.; Mao, S.S. Titanium dioxide nanomaterials: Synthesis, properties, modifications and applications. Chem. Rev. 2007, 107, 2891-2959. [CrossRef] [PubMed]

10. Tao, J.; Luttrell, T.; Batzill, M. A two-dimensional phase of $\mathrm{TiO}_{2}$ with a reduced bandgap. Nat. Chem. 2011, 3, 296-300. [CrossRef]

11. Raizada, P.; Kumari, J.; Shandilya, P.; Dhiman, R.; Singh, V.P.; Singh, P. Magnetically retrievable $\mathrm{Bi}_{2} \mathrm{WO}_{6} / \mathrm{Fe}_{3} \mathrm{O}_{4}$ immobilized on graphene sand composite for investigation of photocatalytic mineralization of oxytetracycline and ampicillin. Process. Saf. Environ. Prot. 2017, 106, 104-116. [CrossRef]

12. Pérez-Molina, Á.; Morales-Torres, S.; Maldonado-Hódar, F.J.; Pastrana-Martínez, L.M. Functionalized Graphene Derivatives and $\mathrm{TiO}_{2}$ for High Visible Light Photodegradation of Azo Dyes. Nanomaterials 2020, 10, 1106. [CrossRef] 
13. Ong, C.B.; Ng, L.Y.; Mohammad, A.W. A review of ZnO nanoparticles as solar photocatalysts: Synthesis, mechanisms and applications. Renew. Sustain. Energy Rev. 2018, 81, 536-551. [CrossRef]

14. Sampaio, M.J.; Lima, M.J.; Baptista, D.L.; Silva, A.M.T.; Silva, C.G.; Faria, J.L. Ag-loaded ZnO materials for photocatalytic water treatment. Chem. Eng. J. 2017, 318, 95-102. [CrossRef]

15. McLaren, A.; Valdes-Solis, T.; Li, G.; Tsang, S.C. Shape and Size Effects of ZnO Nanocrystals on Photocatalytic Activity. J. Am. Chem. Soc. 2009, 131, 12540-12541. [CrossRef] [PubMed]

16. Kołodziejczak-Radzimska, A.; Jesionowski, T. Zinc oxide-From synthesis to application: A review. Materials 2014, 7, $2833-2881$. [CrossRef]

17. Wan, Q.; Li, Q.H.; Chen, Y.J.; Wang, T.-H.; He, X.L.; Li, J.P.; Lin, C.L. Fabrication and ethanol sensing characteristics of ZnO nanowire gas sensors. Appl. Phys. Lett. 2004, 84, 3654-3656. [CrossRef]

18. Dai, K.; Lu, L.; Liang, C.; Dai, J.; Zhu, G.; Liu, Z.; Liu, Q.; Zhang, Y. Graphene oxide modified ZnO nanorods hybrid with high reusable photocatalytic activity under UV-LED irradiation. Mater. Chem. Phys. 2014, 143, 1410-1416. [CrossRef]

19. Qin, J.; Zhang, X.; Yang, C.; Cao, M.; Ma, M.; Liu, R. ZnO microspheres-reduced graphene oxide nanocomposite for photocatalytic degradation of methylene blue dye. Appl. Surf. Sci. 2017, 392, 196-203. [CrossRef]

20. Al-Rawashdeh, N.A.F.; Allabadi, O.; Aljarrah, M.T. Photocatalytic Activity of Graphene Oxide/Zinc Oxide Nanocomposites with Embedded Metal Nanoparticles for the Degradation of Organic Dyes. ACS Omega 2020, 5, 28046-28055. [CrossRef]

21. Toporovska, L.; Turko, B.; Savchak, M.; Seyedi, M.; Luzinov, I.; Kostruba, A.; Kapustianyk, V.; Vaskiv, A. Zinc oxide: Reduced graphene oxide nanocomposite film for heterogeneous photocatalysis. Opt. Quantum Electron. 2019, 52, 21. [CrossRef]

22. Hoffman, R.L.; Norris, B.J.; Wager, J.F. ZnO-based transparent thin-film transistors. Appl. Phys. Lett. 2003, 82, 733-735. [CrossRef]

23. Keis, K.; Magnusson, E.; Lindström, H.; Lindquist, S.-E.; Hagfeldt, A. A 5\% efficient photoelectrochemical solar cell based on nanostructured $\mathrm{ZnO}$ electrodes. Sol. Energy Mater. Sol. Cells 2002, 73, 51-58. [CrossRef]

24. Ahmed, G.; Hanif, M.; Zhao, L.; Hussain, M.; Khan, J.; Liu, Z. Defect engineering of ZnO nanoparticles by graphene oxide leading to enhanced visible light photocatalysis. J. Mol. Catal. A Chem. 2016, 425, 310-321. [CrossRef]

25. Kumar, S.G.; Rao, K.S.R.K. Zinc oxide based photocatalysis: Tailoring surface-bulk structure and related interfacial charge carrier dynamics for better environmental applications. Rsc Adv. 2015, 5, 3306-3351. [CrossRef]

26. Bizarro, M.; Sánchez-Arzate, A.; Garduno-Wilches, I.; Alonso, J.C.; Ortiz, A. Synthesis and characterization of ZnO and ZnO: Al by spray pyrolysis with high photocatalytic properties. Catal. Today 2011, 166, 129-134. [CrossRef]

27. Li, Y.; Della Valle, F.; Simonnet, M.; Yamada, I.; Delaunay, J.-J. Competitive surface effects of oxygen and water on UV photoresponse of ZnO nanowires. Appl. Phys. Lett. 2009, 94, 23110. [CrossRef]

28. Deng, Z.; Chen, M.; Gu, G.; Wu, L. A facile method to fabricate ZnO hollow spheres and their photocatalytic property. J. Phys. Chem. B 2008, 112, 16-22. [CrossRef]

29. Lu, F.; Cai, W.; Zhang, Y. ZnO hierarchical micro/nanoarchitectures: Solvothermal synthesis and structurally enhanced photocatalytic performance. Adv. Funct. Mater. 2008, 18, 1047-1056. [CrossRef]

30. Sung, Y.-H.; Frolov, V.D.; Pimenov, S.M.; Wu, J.-J. Investigation of charge transfer in Au nanoparticle-ZnO nanosheet composite photocatalysts. Phys. Chem. Chem. Phys. 2012, 14, 14492-14494. [CrossRef]

31. Zheng, Y.; Chen, C.; Zhan, Y.; Lin, X.; Zheng, Q.; Wei, K.; Zhu, J. Photocatalytic activity of Ag/ZnO heterostructure nanocatalyst: Correlation between structure and property. J. Phys. Chem. C 2008, 112, 10773-10777. [CrossRef]

32. Kovalenko, A.; Pourroy, G.; Crégut, O.; Gallart, M.; Hönerlage, B.; Gilliot, P. Evidence of unintentional n-doping in ZnO nanorods. J. Phys. Chem. C 2010, 114, 9498-9502. [CrossRef]

33. Lin, Y.-G.; Hsu, Y.-K.; Chen, Y.-C.; Chen, L.-C.; Chen, S.-Y.; Chen, K.-H. Visible-light-driven photocatalytic carbon-doped porous $\mathrm{ZnO}$ nanoarchitectures for solar water-splitting. Nanoscale 2012, 4, 6515-6519. [CrossRef] [PubMed]

34. Sun, L.-W.; Shi, H.-Q.; Li, W.-N.; Xiao, H.-M.; Fu, S.-Y.; Cao, X.-Z.; Li, Z.-X. Lanthanum-doped ZnO quantum dots with greatly enhanced fluorescent quantum yield. J. Mater. Chem. 2012, 22, 8221-8227. [CrossRef]

35. Li, B.; Liu, T.; Wang, Y.; Wang, Z. ZnO/graphene-oxide nanocomposite with remarkably enhanced visible-light-driven photocatalytic performance. J. Colloid Interface Sci. 2012, 377, 114-121. [CrossRef] [PubMed]

36. Dai, K.; Dawson, G.; Yang, S.; Chen, Z.; Lu, L. Large scale preparing carbon nanotube/zinc oxide hybrid and its application for highly reusable photocatalyst. Chem. Eng. J. 2012, 191, 571-578. [CrossRef]

37. Liu, W.M.; Li, J.; Zhang, H.Y. Reduced graphene oxide modified zinc oxide composites synergistic photocatalytic activity under visible light irradiation. Optik 2020, 207, 163778. [CrossRef]

38. Sampaio, M.J.; Bacsa, R.R.; Benyounes, A.; Axet, R.; Serp, P.; Silva, C.G.; Silva, A.M.T.; Faria, J.L. Synergistic effect between carbon nanomaterials and $\mathrm{ZnO}$ for photocatalytic water decontamination. J. Catal. 2015, 331, 172-180. [CrossRef]

39. Johar, M.A.; Afzal, R.A.; Alazba, A.A.; Manzoor, U. Photocatalysis and bandgap engineering using ZnO nanocomposites. Adv. Mater. Sci. Eng. 2015, 2015. [CrossRef]

40. Xue, B.; Zou, Y. High photocatalytic activity of ZnO-graphene composite. J. Colloid Interface Sci. 2018, 529, 306-313. [CrossRef]

41. Raizada, P.; Sudhaik, A.; Singh, P. Photocatalytic water decontamination using graphene and ZnO coupled photocatalysts: A review. Mater. Sci. Energy Technol. 2019, 2, 509-525. [CrossRef]

42. Flores, K.; Valdes, C.; Ramirez, D.; Eubanks, T.M.; Lopez, J.; Hernandez, C.; Alcoutlabi, M.; Parsons, J.G. The effect of hybrid zinc oxide/graphene oxide ( $\mathrm{ZnO} / \mathrm{GO}$ ) nano-catalysts on the photocatalytic degradation of simazine. Chemosphere 2020, $259,127414$. [CrossRef] [PubMed] 
43. Schelonka, D.; Slušná, M.; Tolasz, J.; Popelková, D.; Ecorchard, P. ZnO-GO Composite with for Photocatalytic Applications. Mater. Today Proc. 2016, 3, 2679-2687. [CrossRef]

44. Víctor-Román, S.; García-Bordejé, E.; Hernández-Ferrer, J.; González-Domínguez, J.M.; Ansón-Casaos, A.; Silva, A.M.T.; Maser, W.K.; Benito, A.M. Controlling the surface chemistry of graphene oxide: Key towards efficient ZnO-GO photocatalysts. Catal. Today 2020, 357, 350-360. [CrossRef]

45. Morales-Torres, S.; Pastrana-Martínez, L.M.; Figueiredo, J.L.; Faria, J.L.; Silva, A.M.T. Design of graphene-based TiO 2 photocatalysts-A review. Environ. Sci. Pollut. Res. 2012, 19, 3676-3687. [CrossRef] [PubMed]

46. Han, W.; Ren, L.; Qi, X.; Liu, Y.; Wei, X.; Huang, Z.; Zhong, J. Synthesis of CdS/ZnO/graphene composite with high-efficiency photoelectrochemical activities under solar radiation. Appl. Surf. Sci. 2014, 299, 12-18. [CrossRef]

47. Li, X.; Wang, Q.; Zhao, Y.; Wu, W.; Chen, J.; Meng, H. Green synthesis and photo-catalytic performances for ZnO-reduced graphene oxide nanocomposites. J. Colloid Interface Sci. 2013, 411, 69-75. [CrossRef]

48. Karthik, R.; Thambidurai, S. Synthesis of cobalt doped $\mathrm{ZnO} /$ reduced graphene oxide nanorods as active material for heavy metal ions sensor and antibacterial activity. J. Alloys Compd. 2017, 715, 254-265. [CrossRef]

49. Zheng, W.T.; Ho, Y.M.; Tian, H.W.; Wen, M.; Qi, J.L.; Li, Y.A. Field emission from a composite of graphene sheets and ZnO nanowires. J. Phys. Chem. C 2009, 113, 9164-9168. [CrossRef]

50. Ameen, S.; Akhtar, M.S.; Song, M.; Shin, H.S. Vertically aligned ZnO nanorods on hot filament chemical vapor deposition grown graphene oxide thin film substrate: Solar energy conversion. ACS Appl. Mater. Interfaces 2012, 4, 4405-4412. [CrossRef]

51. Lu, Q.; Pan, X.; Wang, W.; Zhou, Y.; Ye, Z. Ultraviolet photodetector based on nanostructured ZnO-reduced graphene oxide composite. Appl. Phys. A 2018, 124, 733. [CrossRef]

52. Tien, L.C.; Pearton, S.J.; Norton, D.P.; Ren, F. Synthesis and microstructure of vertically aligned ZnO nanowires grown by high-pressure-assisted pulsed-laser deposition. J. Mater. Sci. 2008, 43, 6925-6932. [CrossRef]

53. Pham, C.V.; Repp, S.; Thomann, R.; Krueger, M.; Weber, S.; Erdem, E. Charge transfer and surface defect healing within ZnO nanoparticle decorated graphene hybrid materials. Nanoscale 2016, 8, 9682-9687. [CrossRef] [PubMed]

54. Zhang, Y.; Li, H.; Pan, L.; Lu, T.; Sun, Z. Capacitive behavior of graphene-ZnO composite film for supercapacitors. J. Electroanal. Chem. 2009, 634, 68-71. [CrossRef]

55. Wojnarowicz, J.; Chudoba, T.; Lojkowski, W. A Review of Microwave Synthesis of Zinc Oxide Nanomaterials: Reactants, Process Parameters and Morphoslogies. Nanomaterials 2020, 10, 1086. [CrossRef]

56. Hamdi, M. Toxicity and biodegradability of olive mill wastewaters in batch anaerobic digestion. Appl. Biochem. Biotechnol. 1992, 37, 155-163. [CrossRef]

57. Hummers, W.S., Jr.; Offeman, R.E. Preparation of graphitic oxide. J. Am. Chem. Soc. 1958, 80, 1339. [CrossRef]

58. Pastrana-Martínez, L.M.; Morales-Torres, S.; Likodimos, V.; Figueiredo, J.L.; Faria, J.L.; Falaras, P.; Silva, A.M.T. Advanced nanostructured photocatalysts based on reduced graphene oxide- $\mathrm{TiO}_{2}$ composites for degradation of diphenhydramine pharmaceutical and methyl orange dye. Appl. Catal. B Environ. 2012, 123-124, 241-256. [CrossRef]

59. Tian, C.; Zhang, Q.; Wu, A.; Jiang, M.; Liang, Z.; Jiang, B.; Fu, H. Cost-effective large-scale synthesis of ZnO photocatalyst with excellent performance for dye photodegradation. Chem. Commun. 2012, 48, 2858-2860. [CrossRef]

60. Morales-Torres, S.; Pastrana-Martínez, L.M.; Figueiredo, J.L.; Faria, J.L.; Silva, A.M.T. Graphene oxide-P25 photocatalysts for degradation of diphenhydramine pharmaceutical and methyl orange dye. Appl. Surf. Sci. 2013, 275, 361-368. [CrossRef]

61. Brunauer, S.; Deming, L.S.; Deming, W.E.; Teller, E. On a Theory of the van der Waals Adsorption of Gases. J. Am. Chem. Soc. 1940, 62, 1723-1732. [CrossRef]

62. Sing, K.S.W.; Everett, D.H.; Haul, R.A.W.; Moscou, L.; Pierotti, R.A.; Rouquerol, J.; Siemieniewska, T. Reporting Physisorption Data for Gas/Solid Systems with Special Reference to the Determination of Surface Area and Porosity. Pure Appl. Chem. 1985, 57, 603-619. [CrossRef]

63. Barrett, E.P.; Joyner, L.G.; Halenda, P.P. The Determination of Pore Volume and Area Distributions in Porous Substances. I. Computations from Nitrogen Isotherms. J. Am. Chem. Soc. 1951, 73, 373-380. [CrossRef]

64. Morales-Torres, S.; Silva, T.L.S.; Pastrana-Martínez, L.M.; Brandão, A.T.S.C.; Figueiredo, J.L.; Silva, A.M.T. Modification of the surface chemistry of single- and multi-walled carbon nanotubes by $\mathrm{HNO}_{3}$ and $\mathrm{H}_{2} \mathrm{SO}_{4}$ hydrothermal oxidation for application in direct contact membrane distillation. Phys. Chem. Chem. Phys. 2014, 16, 12237-12250. [CrossRef]

65. Ferro-García, M.A.; Rivera-Utrilla, J.; Bautista-Toledo, I.; Moreno-Castilla, C. Adsorption of Humic Substances on Activated Carbon from Aqueous Solutions and Their Effect on the Removal of Cr(III) Ions. Langmuir 1998, 14, 1880-1886. [CrossRef]

66. Newcombe, G.; Hayes, R.; Drikas, M. Granular activated carbon: Importance of surface properties in the adsorption of naturally occurring organics. Colloids Surf. A Physicochem. Eng. Asp. 1993, 78, 65-71. [CrossRef]

67. Cullity, B.D.; Stock, S.R. Elements of X-ray Diffraction, 3rd ed.; Prentice-Hall: New York, NY, USA, 2001.

68. Zhou, D.; Cheng, Q.-Y.; Han, B.-H. Solvothermal synthesis of homogeneous graphene dispersion with high concentration. Carbon 2011, 49, 3920-3927. [CrossRef]

69. Pastrana-Martínez, L.M.; Morales-Torres, S.; Likodimos, V.; Falaras, P.; Figueiredo, J.L.; Faria, J.L.; Silva, A.M.T. Role of oxygen functionalities on the synthesis of photocatalytically active graphene- $\mathrm{TiO}_{2}$ composites. Appl. Catal. B Environ. 2014, 158-159, 329-340. [CrossRef] 
70. Zarrabi, M.; Haghighi, M.; Alizadeh, R. Sonoprecipitation dispersion of ZnO nanoparticles over graphene oxide used in photocatalytic degradation of methylene blue in aqueous solution: Influence of irradiation time and power. Ultrason. Sonochemistry 2018, 48, 370-382. [CrossRef] [PubMed]

71. Noei, H.; Qiu, H.; Wang, Y.; Löffler, E.; Wöll, C.; Muhler, M. The identification of hydroxyl groups on ZnO nanoparticles by infrared spectroscopy. Phys. Chem. Chem. Phys. 2008, 10, 7092-7097. [CrossRef] [PubMed]

72. Silva, C.G.; Sampaio, M.J.; Carabineiro, S.A.C.; Oliveira, J.W.L.; Baptista, D.L.; Bacsa, R.; Machado, B.F.; Serp, P.; Figueiredo, J.L.; Silva, A.M.T.; et al. Developing highly active photocatalysts: Gold-loaded ZnO for solar phenol oxidation. J. Catal. 2014, 316, 182-190. [CrossRef]

73. Kołodziejczak-Radzimska, A.; Markiewicz, E.; Jesionowski, T. Structural Characterisation of ZnO Particles Obtained by the Emulsion Precipitation Method. J. Nanomater. 2012, 2012, 656353. [CrossRef]

74. Al-Gaashani, R.; Radiman, S.; Daud, A.R.; Tabet, N.; Al-Douri, Y. XPS and optical studies of different morphologies of ZnO nanostructures prepared by microwave methods. Ceram. Int. 2013, 39, 2283-2292. [CrossRef]

75. Pastrana-Martínez, L.M.; Morales-Torres, S.; Carabineiro, S.A.C.; Buijnsters, J.G.; Figueiredo, J.L.; Silva, A.M.T.; Faria, J.L. Photocatalytic activity of functionalized nanodiamond- $\mathrm{TiO}_{2}$ composites towards water pollutants degradation under UV/Vis irradiation. Appl. Surf. Sci. 2018, 458, 839-848. [CrossRef]

76. Pastrana-Martínez, L.M.; Morales-Torres, S.; Papageorgiou, S.K.; Katsaros, F.K.; Romanos, G.E.; Figueiredo, J.L.; Faria, J.L.; Falaras, P.; Silva, A.M.T. Photocatalytic behaviour of nanocarbon-TiO2 composites and immobilization into hollow fibres. Appl. Catal. B Environ. 2013, 142-143, 101-111. [CrossRef]

77. Zhou, X.; Shi, T.; Zhou, H. Hydrothermal preparation of ZnO-reduced graphene oxide hybrid with high performance in photocatalytic degradation. Appl. Surf. Sci. 2012, 258, 6204-6211. [CrossRef]

78. Lv, T.; Pan, L.; Liu, X.; Lu, T.; Zhu, G.; Sun, Z. Enhanced photocatalytic degradation of methylene blue by ZnO-reduced graphene oxide composite synthesized via microwave-assisted reaction. J. Alloys Compd. 2011, 509, 10086-10091. [CrossRef]

79. Srikant, V.; Clarke, D.R. On the optical band gap of zinc oxide. J. Appl. Phys. 1998, 83, 5447-5451. [CrossRef]

80. Yang, N.; Zhai, J.; Wang, D.; Chen, Y.; Jiang, L. Two-Dimensional Graphene Bridges Enhanced Photoinduced Charge Transport in Dye-Sensitized Solar Cells. ACS Nano 2010, 4, 887-894. [CrossRef]

81. Li, B.; Cao, H. ZnO@graphene composite with enhanced performance for the removal of dye from water. J. Mater. Chem. 2011, 21, 3346-3349. [CrossRef]

82. Xiang, Q.; Yu, J.; Wong, P.K. Quantitative characterization of hydroxyl radicals produced by various photocatalysts. J. Colloid Interface Sci. 2011, 357, 163-167. [CrossRef]

83. Xiao, Q.; Si, Z.; Zhang, J.; Xiao, C.; Tan, X. Photoinduced hydroxyl radical and photocatalytic activity of samarium-doped TiO 2 nanocrystalline. J. Hazard. Mater. 2008, 150, 62-67. [CrossRef]

84. Ishibashi, K.-i.; Fujishima, A.; Watanabe, T.; Hashimoto, K. Detection of active oxidative species in $\mathrm{TiO}_{2}$ photocatalysis using the fluorescence technique. Electrochem. Commun. 2000, 2, 207-210. [CrossRef]

85. Banerjee, S.; Pillai, S.C.; Falaras, P.; O'Shea, K.E.; Byrne, J.A.; Dionysiou, D.D. New Insights into the Mechanism of Visible Light Photocatalysis. J. Phys. Chem. Lett. 2014, 5, 2543-2554. [CrossRef] [PubMed]

86. Rengifo-Herrera, J.A.; Pierzchała, K.; Sienkiewicz, A.; Forró, L.; Kiwi, J.; Pulgarin, C. Abatement of organics and Escherichia coli by $\mathrm{N}, \mathrm{S}$ co-doped $\mathrm{TiO}_{2}$ under $\mathrm{UV}$ and visible light. Implications of the formation of singlet oxygen $\left({ }^{1} \mathrm{O}_{2}\right)$ under visible light. Appl. Catal. B Environ. 2009, 88, 398-406. [CrossRef]

87. Cruz, M.; Gomez, C.; Duran-Valle, C.J.; Pastrana-Martínez, L.M.; Faria, J.L.; Silva, A.M.T.; Faraldos, M.; Bahamonde, A. Bare TiO 2 and graphene oxide $\mathrm{TiO}_{2}$ photocatalysts on the degradation of selected pesticides and influence of the water matrix. Appl. Surf. Sci. 2017, 416, 1013-1021. [CrossRef]

88. Fu, H.; Xu, T.; Zhu, S.; Zhu, Y. Photocorrosion inhibition and enhancement of photocatalytic activity for ZnO via hybridization with C60. Environ. Sci. Technol. 2008, 42, 8064-8069. [CrossRef]

89. Wang, Y.; Shi, R.; Lin, J.; Zhu, Y. Enhancement of photocurrent and photocatalytic activity of ZnO hybridized with graphite-like C 3 N 4. Energy Environ. Sci. 2011, 4, 2922-2929. [CrossRef]

90. Lupa, L.; Cocheci, L.; Trica, B.; Coroaba, A.; Popa, A. Photodegradation of Phenolic Compounds from Water in the Presence of a Pd-Containing Exhausted Adsorbent. Appl. Sci. 2020, 10, 8440. [CrossRef]

91. Araña, J.; Doña-Rodríguez, J.M.; Portillo-Carrizo, D.; Fernández-Rodríguez, C.; Pérez-Peña, J.; González Díaz, O.; Navío, J.A.; Macías, M. Photocatalytic degradation of phenolic compounds with new $\mathrm{TiO}_{2}$ catalysts. Appl. Catal. B Environ. 2010, 100, 346-354. [CrossRef]

92. Murcia Mesa, J.J.; García Arias, J.A.; Rojas, H.A.; Cárdenas Espinosa, O.E. Photocatalytic degradation of Phenol, Catechol and Hydroquinone over Au-ZnO nanomaterials. Rev. Fac. Ing. Univ. Antioq. 2020, 94, 24-32. [CrossRef]

93. Choquette-Labbé, M.; Shewa, W.A.; Lalman, J.A.; Shanmugam, S.R. Photocatalytic Degradation of Phenol and Phenol Derivatives Using a Nano- $\mathrm{TiO}_{2}$ Catalyst: Integrating Quantitative and Qualitative Factors Using Response Surface Methodology. Water 2014, 6, 1785-1806. [CrossRef]

94. Al-Kandari, H.; Abdullah, A.M.; Mohamed, A.M.; Al-Kandari, S. Enhanced photocatalytic degradation of a phenolic compounds' mixture using a highly efficient $\mathrm{TiO} 2$ /reduced graphene oxide nanocomposite. J. Mater. Sci. 2016, 51, 8331-8345. [CrossRef]

95. Tao, Y.; Cheng, Z.L.; Ting, K.E.; Yin, X.J. Photocatalytic Degradation of Phenol Using a Nanocatalyst: The Mechanism and Kinetics. J. Catal. 2013, 2013, 364275. [CrossRef] 
96. Hayati, F.; Isari, A.A.; Fattahi, M.; Anvaripour, B.; Jorfi, S. Photocatalytic decontamination of phenol and petrochemical wastewater through $\mathrm{ZnO} / \mathrm{TiO}_{2}$ decorated on reduced graphene oxide nanocomposite: Influential operating factors, mechanism, and electrical energy consumption. RSC Adv. 2018, 8, 40035-40053. [CrossRef]

97. Malekshoar, G.; Pal, K.; He, Q.; Yu, A.; Ray, A.K. Enhanced Solar Photocatalytic Degradation of Phenol with Coupled GrapheneBased Titanium Dioxide and Zinc Oxide. Ind. Eng. Chem. Res. 2014, 53, 18824-18832. [CrossRef] 